MieKe BAL

\title{
RUCH: KINOWOŚĆ W MALARSTWIE I LITERATURZE *
}

\author{
Spotkanie dwóch dyscyplin nie ma miejsca wtedy, \\ gdy jedna z nich oświetla drugą, ale wtedy, \\ gdy jedna dyscyplina uświadamia sobie, \\ że musi rozwiązać dla siebie i swoimi środkami \\ problem podobny do tego, któremu stawia czoło ta druga.
}

(Gilles Deleuze) $^{1}$

Zamiast używać określnika „kinowy” [cinematic] w sensie odnoszącym się do specyfiki medium lub owego zwyczajnego słowa „ruchomy" w sposób, który mógłby być mylący, sięgam po nie w znaczeniu specyficznie odnoszącym się do obecnego projektu, by zbadać związki pomiędzy trzema artystycznymi obiektami: pre-kinową powieścią Flauberta, naszymi post-kinowymi pracami wideo i obrazami Muncha, które powstały na wczesnym etapie rozwoju kina² ${ }^{2}$ W tym tekście ba-

* Tekst ten jest przekładem pierwszego rozdziału (s. 24-43) oraz fragmentu rozdziału drugiego (s. 57-61) książki Mieke Bal pt. EmmaÉEdvard Looking Sideways: Loneliness and the Cinematic (katalog wystawy w Munch Museum), Oslo-Brussels-New Haven-London 2017. Oryginalny tytuł rozdziału został na użytek tego tłumaczenia zmodyfikowany przez Autorkę. Dzięlkuję Mieke Bal oraz Munch Museum za zgodę na przekład oraz udostępnienie ilustracji - przyp. tłum.

${ }^{1}$ G. Deleuze, The Brain is the Screen. An Interview with Gilles Deleuze, w: The Brain is the Screen. Gilles Deleuze and the Philosophy of Cinema, red. G. Flaxman, Minneapolis-London 2000, s. 367.

${ }^{2}$ Pojawia się pewien problem z przekładem określenia "the cinematic”. Z jednej strony, w literaturze polskojęzycznej, gdy mowa o "the cinematic turn”, tłumaczy się go jako „zwrot kinematograficzny”. Jednak użycie słowa „kinematograficzny”, które wiąże się ściśle z kinem, przemysłem filmowym i rejestracją ruchu, w odniesieniu do Bal nie oddawałoby jej koncentracji na ruchu i różnych jego modalnościach związanych zarówno z dziełem, jak i jego odbiorem, z obrazami ruchomymi i nieruchomymi. „The cinematic” można by także przełożyć jako „to-co-kinowe”, co jednak generowałoby w rozmaitych konstrukcjach 
dam cztery znaczenia ruchu i ich implikacje w trzech obrazach Muncha $^{3}$.

Analizuję, w jaki sposób kilka figuratywnych obrazów przejawia podstawową cechę tego, co określam jako kinowość [the cinematic]: sugestię ruchu. Drugie znaczenie ruchu wiąże się ze specyfiką aktu percepcji. Percepcja to selekcja dokonywana przez percypujący podmiot oraz tego podmiotu wspomnienia. Trzecie znaczenie ruchu jest afektywne. Odnosi się ono do synestezyjnej natury widzenia, a zwłaszcza kluczowej roli taktylności i zmysłu słuchu. Ostatnie znaczenie wiąże się z mocą oddziaływania, która nas porusza i skłania do działania na gruncie społeczno-politycznym.

\section{OBRAZ KINOWY: BIEG, CIĄG, MARSZ}

Galopujący koń, pędząc na oślep w kierunku płaszczyzny pola obrazowego, wywołuje u widzów poczucie zagrożenia (il. 1). Jeśli jednak widz nie jest przerażony, to przynajmniej widzimy, że koń sieje popłoch wśród otaczających go ludzi na obrazie. Było tak w przypadku pionierskiego filmu braci Lumière, ukazującego pociąg wjeżdżający na stację, zatytułowanego L'arrivée d'un train en gare de La Ciotat ( $\mathrm{z}$ roku 1895 lub 1896). Jak to możliwe? W obrazie koń nie może galopować; może jedynie wyglądać, jakby galopował w zatrzymanym „owocnym momencie”, by użyć pojęcia wprowadzonego przez oświeceniowego autora Gottholda Ephraima Lessinga (1729-1781) w jego Laokoonie z roku 1766. Tak więc widz nie ma się czego obawiać. A jednak, nawet jeśli nie odczuwamy strachu, widzimy go; strach jest „w obrazie" ${ }^{\prime \prime}$.

zdaniowych szereg problemów, np. natury stylistycznej. Zdecydowałem się wobec tego na zastosowanie słów „kinowość” i „kinowy”, które, choć niedoskonałe i, zwłaszcza „kinowy”, bardziej powszechne niż np. „kinematograficzny”, wydają się właśnie poprzez ową ogólność otwierać na szerokie spektrum znaczeń, o które chodzi Bal - przyp. tłum.

${ }^{3} \mathrm{Na}$ temat pojęcia kinowości zob. The Cinematic, red. D. Campany, Cambridge, MA, 2007; P. Hesselberth, Cinematic Chronotopes: Here, Now, Me, London 2014. Choć obie pozycje są bardzo użyteczne, w żadnej z nich pojęcie to nie jest stosowane w taki sposób, jak robię to w tej książce [Tam, gdzie Bal używa słowa „rozdział”, odnosząc się do książki, stosuję słowo „tekst" lub jego odpowiednik. W tym zdaniu w oryginale autorka pisze nie o czterech, lecz trzech znaczeniach ruchu, ponieważ czwarte pojawia się w dodanym na użytek tego przekładu fragmencie kolejnego rozdziału. Z tego samego względu dokonałem również kilku innych drobnych korekt redakcyjnych, związanych ze zmianą pierwotnego kontekstu prezentowanego tu studium - przyp. tłum.].

${ }^{4}$ Zob. również trafny komentarz poświęcony tekstowi Lessinga oraz ogólnemu problemowi relacji pomiędzy słowem a obrazem: W.J.T. Mitchell, Iconology: Image, Text, Ideology, Chicago 1985. Na temat strachu pojawiającego się podczas oglądu wczesnych filmów, gdy zbliżenia twarzy postrzegano często jako ścięcie głowy: S. Buck-Morss, The Cinema as 


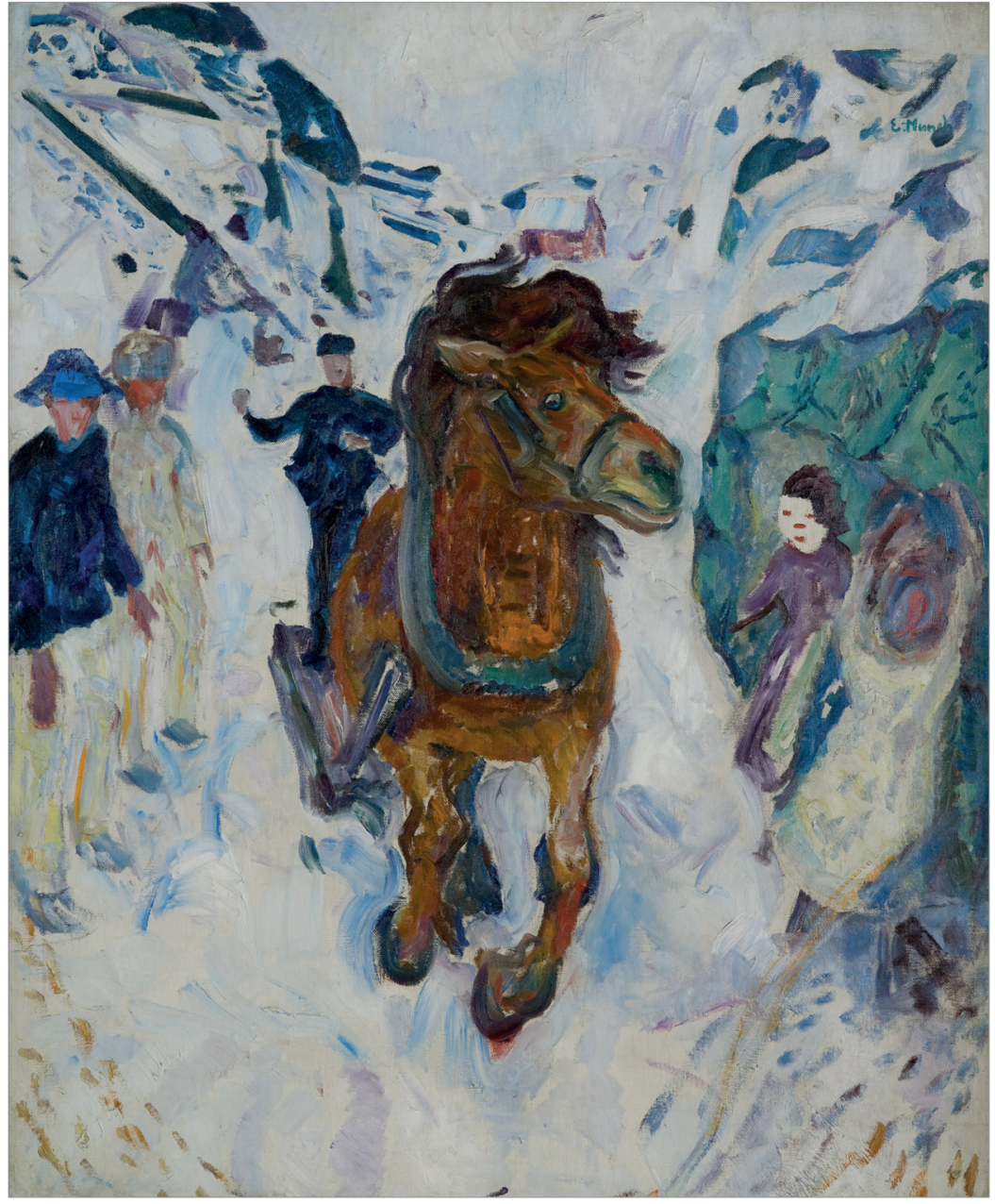

1. Edward Munch, Galopujący koń, 1910-1912, olej na płótnie, $148 \times 120 \mathrm{~cm}$, Munch Museum, Oslo (C) Munch Museum

Półtorej dekady dzieliło film braci Lumière i pracę Muncha powstałą w latach 1910-1912, a do czasu, gdy Munch namalował swój obraz, kino stanowiło już stały element miejskiego życia. Munch chodził na projekcje filmów, a nawet zakupił i sam amatorsko używał kamery. Tak więc stwierdzenie, że obraz ten jest kinowy, mogłoby z łatwością zostać źle odczytane jako całkowicie banalna uwaga. Tymczasem przedmiotem mojej analizy jest coś, co

Prosthesis of Perception, w: The Senses Still: Perception and Memory as Material Culture in Modernity, red. C.N. Seremetakis, Chicago 1993, s. 45-62. 
pozwala na jego porównanie z Flaubertem, który napisał Paniq Bovary kilkadziesiąt lat przed pojawieniem się kina, i z pracą wideo stworzoną sto lat po tym, jak Munch namalował wybrane tu obrazy.

Powszechnie uznaje się kinową jakość pisarstwa Flauberta, a niektórzy badacze sugerowali również kinowy charakter twórczości Muncha. Ta, wydawałoby się, zadziwiająca cecha pisarstwa Flauberta prosi się o odwrócenie tradycyjnej chronologicznej perspektywy, zgodnie z którą techniczny wynalazek wpłynął na artystów. Twierdzę, że można też odwrócić ową argumentację. Artyści kreatywnie wyobrażali sobie i tworzyli wyobrażenia [imaged] sytuacji, które domagały się wynalazku kina. Dlatego, zamiast śledzić wpływ kina na sztukę, sięgam po termin „kinowości” nie jako pojęcie, które przyczynowo wyjaśnia obrazy, ale jako ramę; jako wprowadzenie w dyskusję na temat patrzenia na obrazy - nieruchome i ruchome - opartego na mobilnej relacji pomiędzy obrazem i widzem ${ }^{5}$.

Za pomocą określnika „kinowy” zadaję podwójne pytanie: czym jest ruchomy obraz? A także: co sprawia, że obraz porusza? Pierwsze pytanie jest pytaniem o naturę obrazów, ich sprawczość [agency], efekt i sposób bycia; drugie o związek pomiędzy obrazem i widzem, o sprawczość widza oraz jego lub jej relację z obrazem, włączając w to aspekt afektywny czy emocjonalny. Pisząc o „strachu, który jest «W» obrazie”, próbuję połączyć te dwa pytania w jedno. To właśnie owo połączenie sprawia, że Galopujacy koń to obraz „kinowy”. To samo odnosi się do dwóch innych obrazów, które omówię, adresując kwestię ruchu w sztuce - Pod górę z saniami (także z lat 1910-1912) (il. 2) oraz nieco późniejszy i większy Robotnicy w drodze do domu (1913-1914) (il. 3), uważany za arcydzieło, w szczególny sposób kinowy obraz malarski ${ }^{6}$.

${ }^{5} \mathrm{Na}$ temat kinowej jakości pisarstwa Flauberta zob. P.-M. de Biasi, Gustave Flaubert. Une manière spéciale de vivre, Paris 2009. Autor analizuje sposób, w jaki Flaubert robił notatki na temat możliwych „planów”, odwiedzanych miejsc i jak badał możliwe „ujęcia”, zwracając uwagę na to, że Flaubert nazywał swoje szkice „scenariuszami”. Owe scenariusze czy scenopisy zostały opublikowane w późnym pełnym wydaniu wszystkich szkiców, wersji (których było wiele) i notatek przygotowawczych. Publikacja ta stanowi moje podstawowe źródło. Jeśli kino by wtedy istniało, łatwo można było dostrzec [we Flaubercie - przyp. tłum.] reżysera przy pracy. G. Flaubert [1857], Madame Bovary, vol. 1 des Oeuvres completes des Gustave Flaubert, Tome 1. Edition nouvelle etablie, d'apres les manuscrits inédits de Flaubert, par la Société des Études littéraires françaises, contenant les scénarios et plans des divers romans, la collection complète des Carnets, les notes et documents de Flaubert, avec les notices historiques etc critiques, et illustres d'images contemporaines, Paris 1971.

${ }^{6}$ Wśród badaczy zajmujących się Munchem, którzy wspominają o kinowości, są Arne Eggum, który Robotników w drodze do domu nazywa „studium ruchu” (A. Eggum, Edvard Munch: Paintings, Sketches, and Studies, tłum. R. Christophersen, Oslo 1984, s. 253). 


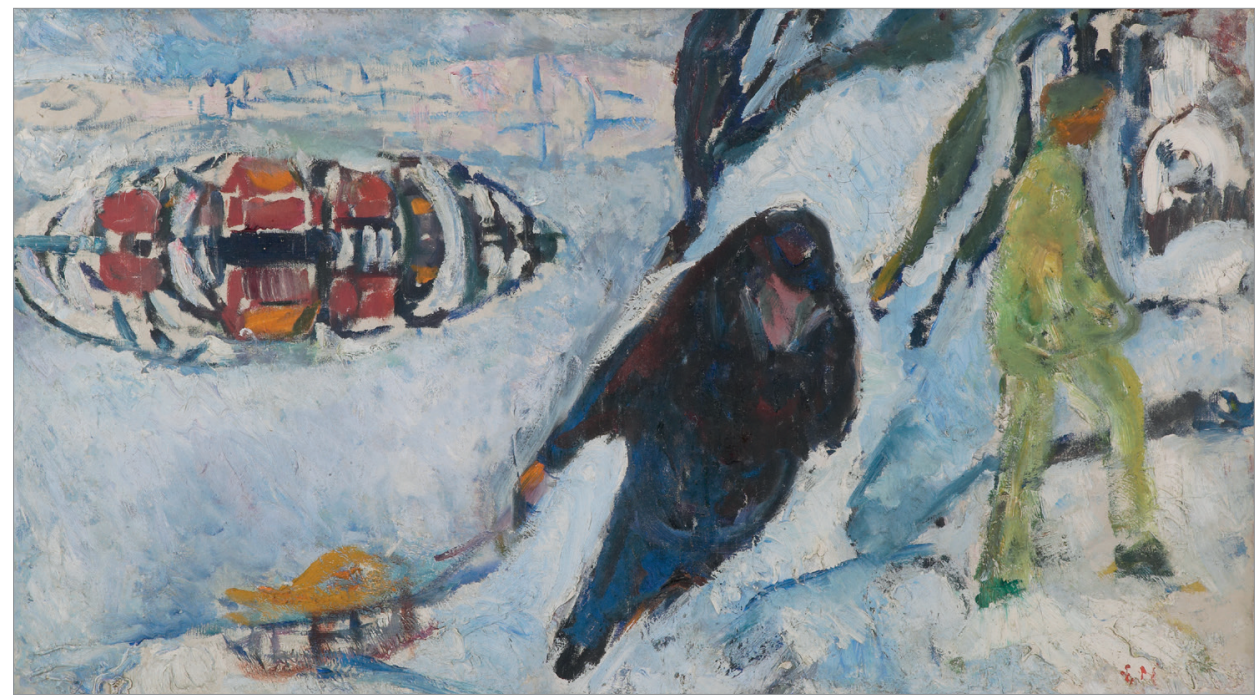

2. Edward Munch, Pod górę z saniami, 1910-1912, olej na płótnie, $65 \times 115,5 \mathrm{~cm}$, Munch Museum, Oslo (C) Munch Museum

Istnieją dwie odmienne odpowiedzi na owe dwa pytania, a istotą tego tekstu jest ich połączenie. „Kinowy” oznacza ruchomy w zarysowanym już sensie, a powodem, dla którego używam tego słowa, jest uniknięcie niejasności, a także różne mylące zastosowania bardziej popularnego słowa „ruch”. Mój wybór tych trzech obrazów jako głównych obiektów teoretycznego namysłu nad tym, co może być kinowego w nieruchomych obrazach, a także bardziej ogólnej refleksji nad tym, jak nieruchome obrazy mogą się także poruszać, to podwójny ruch. Używam tu słowa "ruch”, by podkreślić fakt, że myśl i argumentacja również są formami ruchu. To intelektualne poruszenie może nam pomóc w lepszym zrozumieniu samego myślenia, które odsłania się w kolejnych „ruchach".

Moja teza dotyczy nie tylko ruchu w obrazach i ruchu obrazów, ale także intelektualnego ruchu, który wydarza się, gdy sięgamy po obrazy jako punkt wyjścia, jako rozmówców i nadzorców w naszych próbach rozumienia i teoretyzowania. Tekst ten prezentuje ważne aspekty owego problemu: ruch w „profilmowej rzeczywistości”, ruch „w” obiekcie artystycznym, jego złożoną czasowość i miejsce, które zajmuje w nim widz, a także skutki, jakie owa interakcja niesie dla widza.

W katalogu wystawy „Edvard Munch: The Modern Eye” szczególną uwagę poświęcono zarówno kinowemu aspektowi dzieł, jak i fotograficznej aktywności artysty. 


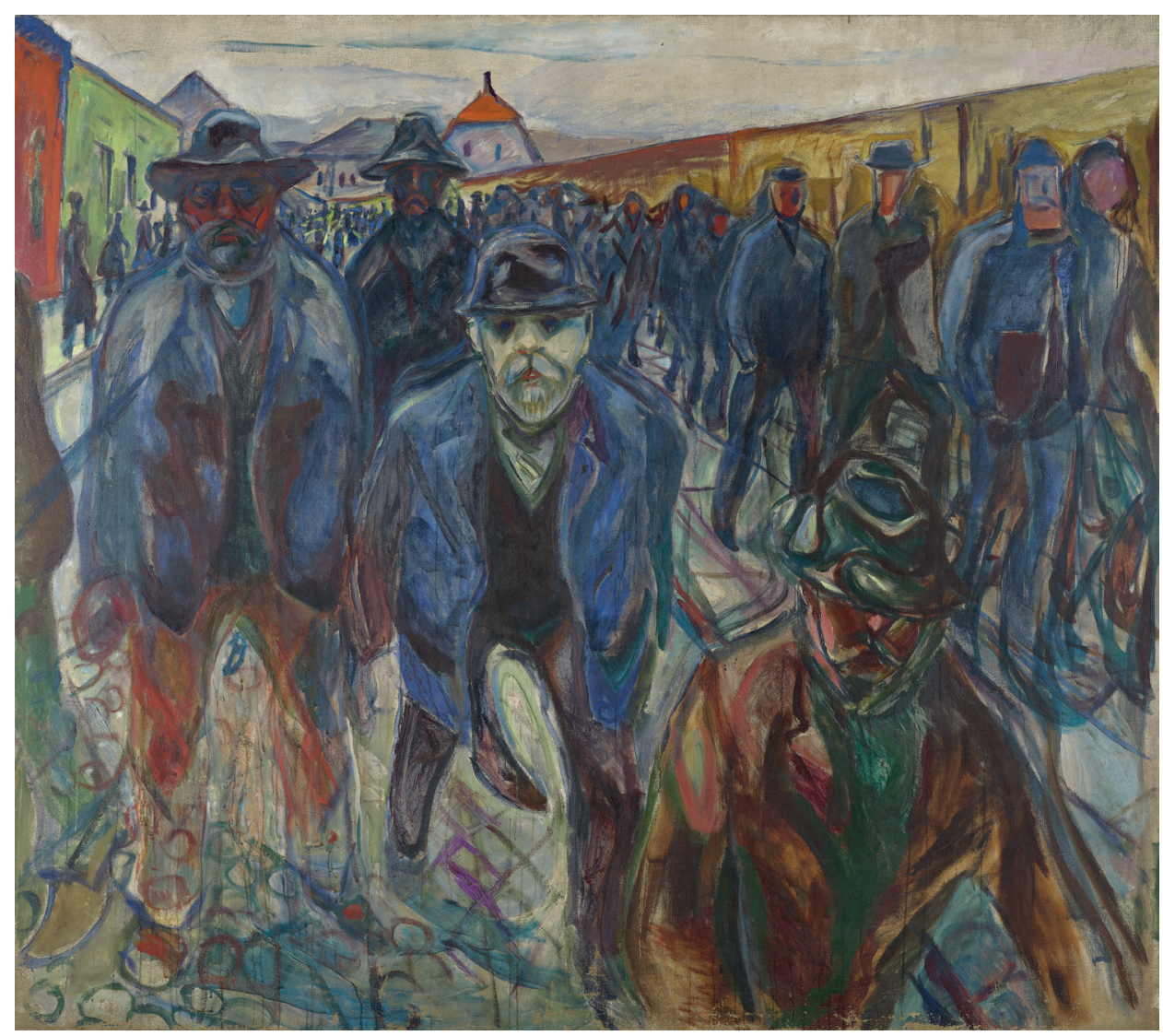

3. Edward Munch, Robotnicy w drodze do domu, 1913-1914, olej na płótnie, $201 \times 227 \mathrm{~cm}$, Munch Museum, Oslo (C) Munch Museum

Dochodzimy zatem do problemu czasowości [time] i jej formalnego (językowego) aspektu czasu [tense] poprzez zagadnienie percepcji rozumianej jako relacja pomiędzy obrazem i widzem. Biorę tu pod uwagę współistnienie aktu percypowania w teraźniejszości i rolę, którą odgrywa w tym akcie pamięć, zarówno indywidualna, jak i zbiorowa, zarówno osobista, jak i kulturowa. Oddziaływanie na widza implikuje polityczną efektywność sztuki. Wspólnie aspekty te definiują poruszającą jakość sztuki, włączając $\mathrm{w}$ to nieruchome obrazy.

W swojej pięknej analizie pełnopostaciowego Portretu Karla Jensena-Hjella z roku 1885 autorstwa Muncha, Øivind Storm Bjerke, choć nie sięga po termin „kinowy”, demonstruje taki właśnie charakter owego obrazu, wskazując na zatrzymanie tego, co było i co będzie ruchem. Pisze on: „Tułów jest nieznacznie wygięty do tyłu, co podkreśla wrażenie, że portretowana osoba 
nagle zatrzymała się, by ocenić sytuację". Interpretuje tę postać jako „rodzaj flanera, obserwatora społecznej rzeczywistości" ${ }^{7}$. Owo nagłe zatrzymanie jest przejawem kinowości; poruszył się, zatrzymuje się, obserwuje i ruszy dalej. Z kolei w kontekście Robotników Reinhold Heller wspomina „liczne obrysy promieniujące z każdej postaci”, które wytwarzaja „pewne i adekwatne poczucie ruchu"s.

Wszystkie trzy obrazy są kinowe w bardziej ogólnym sensie, na różne sposoby, które wspólnie konstytuują kinowość jako pojęcie, które możemy zastosować do analizy nieruchomych obrazów i literatury. Jednak ruch nie jest jedyną kinową cechą, którą możemy brać pod uwagę przy tego rodzaju porównaniu. Rzecz jasna, kino działa za pomocą ruchomych obrazów. Nie tylko poruszają się jego obrazy; również jego sfera „profilmowa” jest zwykle pełna ruchu. Tymczasem istnieje jeszcze wiele innych aspektów, które czynią z obrazu obraz kinowy. Dlatego też, dzięki nim obraz porusza (się) w bogatym, złożonym i wielorakim sensie tego słowa? .

\section{Kadrowanie}

Pierwszy z tych aspektów stanowi kadrowanie [framing]. Używam tego terminu w technicznym, węższym aniżeli szerszym sensie, w którym stanowi on alternatywę dla „kontekstu” ${ }^{10}$. Zarówno wybór profilmowego pola, jak

7 Ø.S. Bierke, Style and Technique as Strategic Devices Used by „the Middle Generation” 1882-86, w: Munch Becoming „Munch”: Artistic Strategies 1880-1892, red. I. Ydstie, M.B. Guleng, Oslo 2008, s. 51.

8 R. Heller, Munch: His Life and Work, Chicago-London 1984, s. 172. [W oryginalnym tekście brakuje początku zdania „Z kolei w kontekście...”, co generowało niejasność co do przedmiotu wypowiedzi Hellera. Uzupełnienie po konsultacji z Autorką - przyp. tłum.].

9 Choć jest to termin z dziedziny filmoznawstwa, a nie historii sztuki, używam określenia „profilmowy”, aby podkreślić kinowy aspekt rzekomo niekinowych obrazów, takich jak obrazy malarskie. „Profilmowy” to termin określający kombinację planu z odgrywaniem ról przez aktorów. Różni się od ruchu kamery i projekcji profilmowego ruchu w filmie.

${ }^{10}$ Pojawia się tu problem przekładu angielskiego słowa framing, które łączy ze sobą przynajmniej dwa wymiary znaczeniowe. Po pierwsze, w technicznym sensie ograniczenia obrazu i pola widzenia, ujęcia w kadr, w fotografii i kinie, ale i - per analogiam - często w sztukach plastycznych, przekłada się je jako „kadrowanie”. O takie znaczenie chodzi tu Bal. Jednocześnie jednak, w dyskursie humanistycznym i innych publikacjach Bal framing tłumaczone jest jako „ramowanie”, oznaczające kontekstualizację opartą na interpretacyjnej subiektywności, w której kontekst nie jest dany, lecz konstruowany. Zgodnie z intencją Autorki, tam, gdzie chodzi przede wszystkim o ów pierwszy sens, stosował będę konsekwentnie pojęcie kadrowania, nie powinniśmy jednak zapominać, że framing jako kadrowanie zawsze ma w odwodzie i potencjalnie wiąże się z owym drugim, szerszym, znaczeniem. Już w kolejnym przypisie Bal dodaje zresztą, że techniczny wymiar stanowi tylko 
i ograniczenia obiektywu stanowią elementy, które sprawiają, że obrazy są tym, czym są i różnią się od rzeczywistości. Taka determinacja, by dokonać wyboru i ograniczyć profilmowe pola, zauważalna jest również w obrazach Muncha. Jednakże obiektyw kamery - w przeciwieństwie do płótna - dyktuje format zwany „współczynnikiem kształtu” - który na przykład kiedyś wyrażany był proporcją $4: 3$, a obecny standard to 16:9. Artysta może dowolnie wybrać rozmiar i proporcje płótna czy tablicy. Każdy z owych trzech obrazów ma inny format i, można by rzec, inny współczynnik kształtu. To sprawia, że oznaki kadrowania jako działania stają się znaczące ${ }^{11}$.

W kinie kadrowanie jest po prostu technicznym, nieuniknionym elementem, ale można je także wydobyć jako aspekt samego medium. To jest rodzaj kadrowania, po które może także sięgnąć malarz. W Galopującym koniu człowiek widoczny po lewej jest przycięty wzdłuż ramienia - to cięcie, którego malarz mógł z łatwością uniknąć. To właśnie rodzaj szczegółu, który czyni autorefleksyjną aluzję do samego medium. Jest to stary jak świat sposób, za pomocą którego artyści utrzymują, że stosowane przez nich medium konstytuuje ich sztukę. W naszych czasach wszechobecnego użycia mediów i dyskusji na ich temat taka medialna refleksyjność jest jak najbardziej aktualna. Nie trzeba jednak dodawać, że nie jest ona specyficzna ani dla danego medium, ani dla czasu.

Stąd w Ważacej perły siedemnastowieczny holenderski malarz Johannes Vermeer (1632-1675) namalował na ścianie gwóźdź, sugerując, że obraz ukazany na prawo od owego gwoździa, co już samo odnosiło się do nienaturalności [artificiality] malarstwa - został przemieszczony z jednego miejsca w inne. Zostało to podkreślone poprzez uwzględnienie znajdującej się na lewo od gwoździa pozostawionej przezeń dziury. Gwóźdź i dziura mają nawet swoje cienie. Trzy próby umieszczenia obrazu w odpowiednim miejscu: to właśnie czynność (równo)ważenia, która stanowi komentarz na temat czynności wykonywanej przez kobietę. Medium i sztuka są jednym. To sprawia, że czynność kadrowania jest również czynnością wydobywającą ową jedność.

Zmiana umiejscowienia namalowanego obrazu pozostawiłaby ślad w fizycznym świecie, ale niekoniecznie w jego przedstawieniu. Zaznaczenie jej nie podkreśla realizmu, ale coś wręcz przeciwnego: fakt, że praca ta jest obrazem. Podobnie przycięcie fragmentu ramienia figury ludzkiej w obrazie, który tak emfatycznie reprezentuje ruch, oznajmia, że obraz kadruje swą profilmo-

jeden $z$ aspektów znaczeniowych tego pojęcia, a jeszcze w następnym odnosi się do filozoficznej dyskusji na temat ramy i ramowania w książce Jacques'a Derridy. „Kadrowanie” nie stanowi już wtedy wspomnianej przez Bal „alternatywy” - przyp. tłum.

${ }^{11}$ Ta materialna, praktyczna forma kadrowania stanowi jedynie jeden jego aspekt. Zob. rozbudowaną analizę: M. Bal, Wędrujące pojęcia w naukach humanistycznych. Krótki przewodnik, tłum. M. Bucholc, Warszawa 2012, s. 161-201 (rozdział 4). 
wą rzeczywistość; wycina jej część. [Gest ten] zamienia obraz w migawkowe ujęcie [snapshot] - mężczyzna w każdym momencie może się wycofać i zniknąć poza kadrem. Wykluczone zostaje w ten sposób naiwne spojrzenie na obraz jako na transparentną, realistyczną reprezentację. Widzimy mężczyznę, ale dzięki owemu przycięciu jesteśmy świadomi, że oglądamy (jedynie) jego obraz. Ponadto przywołane zostaje wszystko to, co znajduje się na zewnątrz w stosunku do pola widzenia. A w końcu wraz z aspektem temporalnym pojawia się ruch. Widz zostaje uaktywniony, by patrzeć $w$ czasie, ponieważ mężczyzna zaraz zniknie ${ }^{12}$.

\section{Montaż}

Inny kluczowy aspekt kina wynika z montażu - także dwuznacznej techniki ${ }^{13}$. Montaż był jednym $z$ awangardowych środków wczesnego kina eksperymentalnego. Pocięcie filmu na kawałki a następnie połączenie fragmentów tak, że cięcia te są niewidoczne, podkreśla materialność taśmy celuloidowej (obecnie cyfrowych plików) a także to, że uczyniono ją niewidzialną, co stanowi pewną umiejętność - stanowi sztukę. Z tego względu obraz Robotnicy $w$ drodze do domu to arcydzieło kinowego malarstwa. Trzy główne postaci wydają się stać nieruchomo, jakby na chwilę zatrzymały swój marsz. A zatem ruch jest implikowany, zatrzymany i - jak sugeruje obraz - będzie kontynuowany, gdy już skończymy się owej scenie przyglądać. Postaci przestają iść jakby dla nas, abyśmy mogli je zobaczyć; widz staje się zatem częścią obrazu. Sytuacja ta podkreśla więc kolejny aspekt sztuki wizualnej - zarówno kina, jak i malarstwa: spotkanie, które sztuka ta aranżuje i ucieleśnia, pomiędzy obrazem i procesem oglądu dokonywanym przez widza. W tym przypadku owo spotkanie akcentuje samą widzialność poprzez pozę postaci, które zwracają się do widza, jakby pytając: „Widzisz nas?”.

Mężczyzna po lewej stoi wyraźnie nieruchomo: nie spieszy się - jedna ręka w kieszeni, druga z zaciśniętą pięścią, nogi rozwarte. To pełnopostaciowy, frontalny portret. To, że jego lewa noga jest nieco cofnięta w stosunku do prawej, sprawia, że można założyć, iż jednak idzie. Rzecz tkwi w owej dwu-

${ }^{12} \mathrm{Na}$ temat gwoździa Vermeera i jego teoretycznych przesłanek zob. M. Bal, Seeing Signs: the Use of Semiotics for the Understanding of Visual Art, w: The Subjects of Art History: Historical Objects in Contemporary Perspectives, red. M.A. Cheetham, M.A. Holly, K. Moxey, New York 1998, s. 74-93. Na temat ramy jako granicy pomiędzy wnętrzem a zewnętrzem oraz podłożem tej idei u Kanta zob. J. Derrida, Prawda w malarstwie, tłum. M. Kwietniewska, Gdańsk 2003.

13 Bal używa słowa „editing” zamiennie z „montage”. W języku polskim, w kontekście montażu kinowego, oba angielskie słowa oznaczają „montaż” - przyp. tłum. 
znaczności: widzowie muszą zdecydować i owa konieczność sprawia, że stają się aktywni. Drugi mężczyzna wykonuje tak gigantyczny krok do przodu, że jego wysunięta noga jest długa, a ta pozostająca w tyle tak krótka, że można by ją pomylić z czymś innym; ten właśnie wielki krok odróżnia go od pierwszego mężczyzny. Dużo mniej rozluźniony, spogląda do góry, co podczas szybkiego marszu stanowi pewien wysiłek. Wydaje się, że został „ujęty” [shot] z góry. Cofnięta noga jest niedookreślona, zwłaszcza że podobny kształt - również brązowy, być może stopa - znajduje się tuż przy niej, odseparowany od mężczyzny widocznego za nim, któremu zostałaby przypisana, jeśliby kierować się realistyczną lekturą obrazu.

Wspólnie te dwie odnogi nadają owej postaci zwierzęcy charakter. Druga postać, która podnosi wzrok w stronę kamery, jest dziwnie osadzona w przestrzeni i w ten sposób zdaje się [nas] przekonywać, że to malarskie przedstawienie jest (także) płaskim obrazem. Świadomość tego podwójnego statusu obrazu pomaga nam odczytać trzecią figurę. Dochodzimy teraz do ogólniejszej wizualnej konkluzji na temat malarstwa, którą sugeruje obraz Muncha. W lekturze perspektywicznej „profilmowego tła” trzeci mężczyzna ulokowany jest przed drugim, ale w oglądzie płaszczyznowym obrazu - po jego prawicy. Ta postać jest proporcjonalnie największa, jeśli weźmiemy pod uwagę rozmiar głów wszystkich trzech mężczyzn, a jego ciało jest przycięte w połowie, nie przez krawędź, ale płaskie pole obrazu [picture plane]. Owa płaskość stanowi kolejny aspekt obrazów, który staje się, dosłownie, pierwszoplanowy. Postać ta może ma przed sobą jakiś wózek, dziecko albo jakiś nieokreślony bagaż i może stać, pchać albo iść. Tym, co widzimy, jest to, że nie możemy zobaczyć, czym się zajmuje ${ }^{14}$.

Niewidzialność to ważne zagadnienie filozofii kultury wizualnej. Francuski filozof Michel Foucault (1926-1984) tak mówi o niewidzialności w kontekście fikcji: „Fikcja nie polega na pokazywaniu tego, co niewidzialne, ale na pokazywaniu, do jakiego stopnia owa niewidzialność widzialnego jest niewidzialna"15. W takim ujęciu brak jasności w przypadku trzeciej postaci jest ważnym, autorefleksyjnym sposobem podkreślenia fikcyjności owej sceny.

${ }^{14}$ Ta kombinacja trzech różnych „ujęć” z różnych pozycji kamery została zauważona przede mną przez wielu badaczy: Zob. zwłaszcza G. Woll, Now It is the Time of the Workers, w: Edvard Munch: Monumental Projects, 1909-1930, Lillehammer 1993, s. 72; idem, I Wonder Whether Art Will Again Belong to Everyone?, w: Edvard Munch: The Soul of Work. A Joint Nordic Exhibition, red. A.T. Halvorsen, A.-L. Walsted, E. Haatvedt, Oslo 1996, s. 27. Na temat montażu zob. S. Eisenstein, Through Theatre to Cinema, w: Film Form, red. i tłum. J. Leyda, New York-London 1998 [1949], s. 3-17.

${ }_{15}$ M. Foucault, Dits et Ecrits, vol. I, Paris 1994, s. 524. 
Używam terminu „profilmowy” dokładnie wtedy, gdy chcę umożliwić połączenie fikcji i rzeczywistości, bez podejmowania kwestii realizmu.

Widoczny po prawej strumień ludzi, za większymi postaciami, daje wrażenie tłumu w ruchu $z$ dwóch względów: po pierwsze, $z$ uwagi na samą liczbę osób, po drugie, ze względu na kontrast pomiędzy nimi a trzema głównymi postaciami. I znów skutecznie zastosowano kadrowanie, a montaż ułatwia włączenie owych ludzkich strumieni w obraz bez konieczności jego unifikacji. Postać przy prawej krawędzi obrazu jest przycięta w taki sposób, że nie można zdecydować, czy jedzie na rowerze, czy nie. Okrągły kształt, ledwie zaznaczony pomiędzy nogami owej postaci, może być kołem albo po prostu jednym $z$ tych abstrakcyjnych, wirujących kształtów, za pomocą których Munch wprowadza ruch.

Fikcja, sugeruje Foucault, służy nam do tego, byśmy zdali sobie sprawę z obecności owego braku klarowności i że choć być może istnieje sposób, by temu zaradzić, to zaprasza nas, byśmy spędzili jakiś czas z obrazem. Dostrzeżenie wyłaniającego się z tego kłębowiska kształtu roweru, a także tego, że pusta twarz postaci wskazuje na "kobietę”, zwłaszcza w owej masie mężczyzn, wymaga bliskiego i odbywającego się w czasie oglądu tego szczegółu; odrobina włosów po bokach różowego, jajowatego kształtu i niewielka, ledwie widoczna obłość na przedzie, sugerująca jej klatkę piersiową. Ta konieczność, by przyjrzeć się szczegółom, to jeszcze jeden sposób, w jaki obraz zmusza widza, by poruszał się „ $\mathrm{w}^{\prime \prime}$ obrazie.

Tym, co sprawia, że ów obraz jest kinowy, jest zatem różnica pomiędzy trzema mężczyznami i otaczającym ich tłumem. Tłum przemieszcza się; mężczyźni zatrzymują się, by zapozować do obrazu. Daje to poczucie, że każdy z nich został "sfilmowany” pod innym kątem, od lewej do prawej: frontalnie, z góry i z boku. Dlatego ów „film”, którym staje się ten obraz, ma charakter eksperymentalny, jest kolażem, a nie po prostu ruchomym obrazem.

Są tu trzy kinowe możliwości. Scena wygląda tak, jakby była nakręcona $z$ różnych kamer. Albo też montaż zamienił ją w wieloekranowy film. Czy też prościej: obraz przedstawia trzy różne, następujące po sobie, zmontowane sekwencyjnie ujęcia. Wybór jednego z nich sprawia, że to widz dokonuje montażu, a aby to zrobić, konieczny jest ruch. Wewnętrzny brak przestrzennej spójności wprowadza weń ruch i aktywizuje widza, by wykonał pracę montowania. Jest to ruch innego rodzaju: nie profilmowy, ale specyficznie filmowy, związany z montażem [editorial] i w tym sensie pomaga nam przeanalizować arkana tego, czym kinowość może być lub jak działać.

Jak pokazuje obraz Robotnicy, kolejną cechą kinowości jest organizacja przestrzeni; najbardziej znanym jej przykładem jest to, co przyzwyczailiśmy się nazywać „perspektywą”. Aparat tworzy perspektywiczne obrazy. W malar- 
stwie jest ona kwestią wyboru, choć perspektywa w pewnym sensie zadomowiła się jako element głównego nurtu przedstawiania. Powszechnie zakłada się, że od czasu jej odkrycia w renesansie zdominowała malarstwo. Jednak wiąże się to $z$ zapominaniem o alternatywnych koncepcjach tworzenia iluzji głębi - za pomocą koloru w baroku i jego negacji w rokoko. A nawet w samym renesansie, przedstawienie chmur czyniło perspektywiczny schemat problematycznym.

Kreująca przestrzeń perspektywa wyraźnie zaznacza się we wszystkich trzech obrazach. W Galopujacym koniu i Robotnikach wiąże się to z wyolbrzymieniem perspektywy linearnej, wydłużeniem jej w celu stworzenia głębokiej przestrzeni. Clément Chéroux w następujący sposób analizuje perspektywiczne strategie Muncha:

[...] kompozycja opiera się, w rzeczy samej, na diagonalnej linii strukturalnej, która przecina powierzchnię obrazu i podkreśla efekt perspektywiczny, na wyrazistych pierwszych planach, które są często odcięte przez ramę, na chwiejnym podłożu [ground], które zdaje się być namalowane z podwyższonego punktu widzenia, a w końcu na wydłużeniu przestrzeni pomiędzy tym, co znajduje się blisko, i tym, co w oddali ${ }^{16}$.

Czasami owo wydłużenie stanowi najbardziej wyrazisty element; niekiedy wyolbrzymiona wysokość [punktu oglądu - F.L.] sprawia, że perspektywa wydaje się wydłużona. Oto sposób, w jaki Munch zwraca uwagę na dylemat wpisany w malarstwo: jako obraz [image] jest ono płaskie; jako wyobrażenie [picture], w sensie przedstawienia [depiction], zmierza do osiągnięcia trójwymiarowości ${ }^{17}$.

16 C. Chéroux, Depth of Field, w: Edvard Munch: The Modern Eye, red. A. Lampe, C. Chéroux, London 2012, s. 83.

17 Zob. klarowną analizę historii myśli na temat perspektywy: H. Damisch, The Origin of Perspective, tłum. J. Goodman, Cambridge, MA, 1994. Na temat chmur jako elementu zakłócającego perspektywę, wraz z religijnym znaczeniem i ontologiczną "dyskusją”, zob. H. Damisch, Teoria /obłoku/. W stronę historii malarstwa, tłum. P. Tarasiewicz, Gdańsk 2011 [1972]. [Zauważmy przy tym, że Bal w swoim tekście w dość nietypowy sposób używa opozycji pojęć image oraz picture, tu przekładanych przeze mnie odpowiednio jako „obraz” i „wyobrażenie”, gdzie to pierwsze odnosi się do przedstawienia uwzględniającego materialną i medialną specyfikę wizualnego nośnika, drugie do tego, co przedstawione. Różni się to na przykład od sposobu kontrastowania ze sobą obu pojęć przez W.J.T. Mitchella, gdzie image to najczęściej obraz niematerialny, picture - konkretny, wyobrażający coś, fizyczny przedmiot. Podobnie image wiąże się z czymś, co gubi lub zmienia swoje materialne medium w koncepcji Hansa Beltinga (zob. np. W.J.T. Mitchell, Wartość dodatkowa obrazów, w: idem, Czego chca obrazy? Pragnienia przedstawień, życie i miłości obrazów, tłum. Ł. Za- 
Coś na kształt przełamania owej przestrzeni wydarza się w Pod górę z saniami (il. 2), lecz jednak w inny sposób. Śnieg namalowany jest grubymi, białymi, szarymi, a miejscami niebieskawymi impastami w postaci skręconych i falistych śladów pędzla. Jeśli brać pod uwagę relacje przestrzenne, to mężczyzna w zieleni usytuowany jest bliżej powierzchni płótna niż ten, który ciągnie sanki; tak jakby ten pierwszy po prostu przechodził, nie zwracając jakiejkolwiek uwagi na ciężką pracę drugiego mężczyzny. Główny bohater [obrazu - F.L.] nie ma twarzy, oczu, jedynie coś na kształt pyska, i widać tylko jedną jego nogę. Kolorowy kształt w lewej, górnej partii obrazu wydaje się być bliżej wzgórza, tak jakby był nawet większy - choć jest $\mathrm{w}$ istocie niewielki - niż byłoby to możliwe dla poszukującego realizmu oka. Zróżnicowany wolumen wzgórza zbudowany został za pomocą niebieskich, zielonych i ciemnobrązowych linii z cieniami. Wolumen ten widać lepiej z pewnej odległości niż z bliska.

Przestrzenne wrażenie obrazu bierze się z równomiernie wyolbrzymionej perspektywy, nie wydłużonej, ale przechylonej czy też opadającej. Jest to widok z góry, który podkreśla stromiznę pagórka i sprawia, że kształt poniżej (w ukazanej scenie) albo powyżej (na płaskim obrazie) jest całkowicie płaski. Początkowo myślałam, że był to statek towarowy. Wynikało to z oglądu zakładającego, że widzę go nie tyle ze szczytu wzgórza, ile z lotu ptaka, z punktu znajdującego się dokładnie nad nim. Taki ogląd można jednak zastosować jedynie w przypadku jego interpretacji jako „statku”. Czyni on obraz tak przestrzennie niespójnym, że zwracamy uwagę na jego status jako obrazu malarskiego - zarówno obrazu (to, co widzimy), jak i wyobrażenia [picture] (co on przedstawia [what it depicts]). Ale przy bliższym oglądzie zauważyłam, że moje błędne odczytanie [misreading] spowodowane było kolejną przestrzenną osobliwością. Jeśli mamy jednak do czynienia z występem lądu w strefę fiordu, to nadal na obu końcach ma on zwodniczy kształt, który mnie zmylił. $\mathrm{W}$ takim razie oferuje on lustrzany obraz domów i ich odbicia w wodzie. Co istotniejsze, szereg domów byłby sfilmowany frontalnie, $z$ naprzeciwka, tak jak mężczyzna po lewej w Robotnikach, co pozostaje w konflikcie $z$ resztą obrazu.

Większa część obrazu jest ujęta $[\text { shot }]^{18} \mathrm{z}$ góry, ale w linii prostej; raczej bardziej z ukosa, ani z lotu ptaka, ani z naprzeciwka, co stanowiłoby dwa

remba, Warszawa 2013, s. 115-116; H. Belting, Antropologia obrazu. Szkice do nauki o obrazie, tłum. M. Bryl, Kraków 2007 - przyp. tłum.].

18 Akurat w tym akapicie Autorka, trochę zaskakująco, sięga po słowo „to shoot”, które może oznaczać filmowanie lub fotografowanie, co z jednej strony wpisuje się w jej kinową terminologię, z drugiej - prowokuje do zadania pytania, dlaczego akurat w odniesieniu do tego obrazu i w tym akapicie, a nie gdzie indziej (z jednym wyjątkiem, s. 288). 
przeciwstawne punkty oglądu - albo mojego błędnego odczytania, albo realistycznie poprawnego. Z kolei scena [fragment z postaciami na wzgórzu - F.L.] wydaje się być ujęta ze szczytu sąsiedniego wzgórza. Ale to również nie jest pojedyncze ujęcie [ a single 'take']. Wyobrażenie mężczyzny ciągnącego sanki ukazuje go w pozycji opartej na ostrym skosie, która po ludzku nie jest możliwa do utrzymania bez utraty równowagi. A zatem musiał on zostać ujęty z punktu znajdującego się wobec niego pod ostrym kątem, co podkreśla jego zmaganie się ze stromym zboczem i ciężkim ładunkiem, który ciągnie.

Mężczyzna w zieleni, przeciwnie, choć znajduje się tuż przy ciągnącym sanki, w porządku płaszczyznowym [in the flat image], stoi wyprostowany i maszeruje bez trudu. To musi być naprzeciwległe ujęcie profilu jego sylwetki z poziomu oka. Jednak wydaje się mniejszy, jakby bardziej oddalony niż ten, który ciężko pracuje, ciągnąc sanki. Znów przestrzenna organizacja obrazu sprawia, że wygląda on bardziej jak kolaż lub wieloekranowy film niż pojedynczy obraz. To sprawia, że widz staje przed zadaniem pogodzenia tych różnych pozycji [postaci - F.L.], tak jakby były one fizycznymi ciałami [a nie elementami przedstawienia - F.L. ${ }^{19}$.

W swojej książce O formie filmowej (1949) rosyjski awangardowy twórca filmowy Siergiej Eisenstein (1898-1948) rozważał estetyczne efekty rozmaitych strategii montażowych. Kluczowym przykładem, który podaje, jest Madame Bovary Flauberta. Tłumaczy on swoje poglądy na temat montażu na przykładzie słynnej sceny Comices agricoles, corocznego targu, podczas którego Rodolphe uwodzi Emmę i staje się jej pierwszym kochankiem. Eisenstein analizuje przenikające się dyskursy urzędników i niedoszłych kochanków jako montaż dźwiękowy ${ }^{20}$. Jego zdaniem montaż to konflikt ${ }^{21}$. Pojęcie

Konsekwentnie przekładam je tutaj, nieco neutralizując jego techniczny wymiar, stosując czasownik „ująć” - przyp. tłum.

19 Gra organizacją przestrzeni to coś więcej niż protest przeciwko dominacji perspektywy linearnej. Zob. N. Verhoeff, Surface Explorations: 3D Moving Images as Cartographies of Time, „Espacio, Tiempo y Forma” 2016, 4, s. 39-58. Jej komentarz demonstruje, jak trójwymiarowy film Wernera Herzoga A Cave of Forgotten Dreams zarówno łączy ze sobą naturalne ściany, które wspierają wielotysiącletnie malunki jaskiniowe, jak i projektuje „kartografię czasu”, która w animacji przywraca do życia dawno minioną przeszłość. Jej analiza pokazuje kulturową istotność autorefleksji medium filmu 3D, ruchomego obrazu w ogóle oraz wspólnego badania czasu i przestrzeni. Verhoeff analizuje uwarstwienie czasu i przestrzeni w ruchomym obrazie i jako taki jej artykuł można uznać za fundamentalną teoretyzację ruchu obrazów [Bal stosuje tu skrót myślowy, pisząc o „fizycznym pogodzeniu różnych pozycji”, który po konsultacji z Autorką pozwalam sobie dla klarowności wywodu rozwinąć - przyp. tłum.].

20 S. Eisenstein, Film Form. Essays in Film Theory, tłum. J. Leyda, New York-London 1977 , s. $12-13$.

${ }^{21}$ S. Eisenstein, Montage is Conflict, w: The Cinematic, s. 30. 
montażu z kreowanymi przez niego sprzecznościami pozwala nam również zrozumieć już dostrzeżony aspekt malarstwa Muncha, lecz nie analizowany pod kątem jego konsekwencji, zwłaszcza dla politycznej wymowy malarstwa. Aspekt ten określam mianem „błędów”.

\section{BŁĘDY}

„Błędy” są charakterystyczną cechą zarówno Muncha, jak i Flauberta. Środki, które tu omawiam, stanowią błędy w odniesieniu do normy technicznej doskonałości, wyznaczanej standardami realizmu. Skupiają one natomiast uwagę na samym medium. Kusząc widzów do popełniania interpretacyjnych błędów, takich jak moje błędne rozpoznanie górnej lewej strony Pod górę jako statku - pozwalają dostrzec dwuznaczności obrazu. Po stronie artysty przesunięcia, pomyłki, usterki, zamazania, złe kadrowanie oraz błędy w rysunku perspektywicznym stanowią przykłady ruchu od jednego obrazu do innego, który wykorzystuje techniczne elementy medium w celu spowodowania zmiany ${ }^{22}$.

Artyści od zawsze troszczyli się o to, by nie stracić śmiałości robienia rzeczy, które uznane byłyby za błędne - na przykład przez konserwatywnych jurorów artystycznych akademii. Takie błędy mogą mieć posmak awangardy. Rozmyślne błędy sprawiają, że widz zwraca uwagę na medium. Nazwanie ich kinowymi jest moim sposobem na to, by połączyć ze sobą ten rodzaj błędów, które popełnia Munch w swoich obrazach, Flaubert w swoim pisarstwie oraz Williams Gamaker i ja w naszych wideo. Własność kinowych błędów tkwi w ich dwojakich skutkach: jeden ich wymiar jest związany z autorefleksyjną orientacją na medium, a drugi, konkretny, generuje znaczenie akurat dyskutowanego dzieła.

Niesamowity „błąd" u Muncha stanowi błyszczące odbicie w okularach postaci w Portrecie Karla Jensena-Hjella. Bjerke tak pisze o tym odbiciu: „Ma funkcję zarówno przyciągającą spojrzenie, jak i podkreślającą znaczenie obserwacji w kulturze wizualnej zdominowanej przez zmysłową percepcję powierzchni"23. Połączenie motywu obserwacji dokonywanej zarówno przez przedstawioną postać, jak i widza sprawia, że ich spojrzenia spotykają

${ }^{22}$ Dobry punkt wyjścia na temat autorefleksyjności medium stanowi znany artykuł Rosalind Krauss Video: the Aesthetics of Narcissism, „October” 1976, 1, s. 50-64. Na temat błędów, które określa mianem „usterek“ [glitches], jako artystycznego środka zob. M. Betancourt, Motion Perception in Movies and Painting: Towards a New Kinetic Art, "Ctheory" 2002, czasopismo internetowe: < https://journals.uvic.ca/index.php/ctheory/article/view/14573> [dostęp: 10 lipca 2020].

${ }^{23}$ Bjerke, Style and Technique, s. 51. 
się na gruncie owej kultury wizualnej. Naddana wartość „usterki” Muncha polega na zwróceniu uwagi na powierzchnie; zarówno jako rdzeń słowa „powierzchowny", rozumianego jako ideologiczna krytyka, jak i jako mnogość obecności odbić, wyraźna we wtedy względnie nowym zjawisku witryn sklepowych ${ }^{24}$. Chodzi tu o dobrze przećwiczoną krytykę (post)modernistycznej kultury wizualnej odnoszącej się do tego, że multiplikacja powierzchni promuje powierzchowność społecznego i indywidualnego życia. Autor zdjęć filmowych, który pochwyciłby błysk w szkle okulara, ryzykowałby, że zostanie zrugany za oczywisty „błąd”. Używane z przymrużeniem oka, słowo „błąd” uwidacznia, jak tradycjonalistyczni eksperci cenzorują innowację, jednocześnie sprawiając, że ich sądy wydają się oczywiste i niemożliwe do zakwestionowania, potwierdzając tym samym tezę Foucaulta na temat niewidzialności.

U Flauberta tego rodzaju strategia błędów często polega na zastosowaniu temporalnych niezgodności czasowników, by szokując czytelników, zmusić ich do zwrócenia uwagi na teksturę dzieła - co odpowiada koncentracji na płaskości obrazu u Muncha. W malarstwie kinowa jakość może być również spotęgowana tym, że jakość obrazu zależna jest od kamery, która ogranicza głębię ostrości. To prawie tak, jakbyśmy widzieli ruch kamery i zmianę ostrości - dwa notoryczne „błędy” filmowania, które, wraz z kadrowaniem, mogą również zostać użyte w celu zaakcentowania pewnych aspektów i znaczeń. Pod tym względem malarz ma większą dowolność niż filmowiec. Może - i robi to - różnicować ostrość i nieostrość, niezależnie od tego, na ile usprawiedliwia to głębia ostrości, czy przedstawiona przestrzeń jest płytka, czy głęboka. Jeśli uznać ów zabieg za kinowy, przybiera on charakter autorefleksyiny. Najbardziej wyraźnie widać to w Pod górę.

W powieści Flauberta przykład porównywalny do Muncha wariacji w „pracy kamery" pojawia się w pierwszym zdaniu piątego rozdziału trzeciej części Pani Bovary. Emma właśnie zaczęła swój związek z Leonem. Wymyśliła sposób, żeby mogli się spotykać co tydzień - pod pretekstem lekcji gry na pianinie. To nasza scena nr 7 - Loving Léon. „C'était le jeudi” (Był czwartek) rozpoczyna rozdział. Użyty czas wskazuje na rutynę. Szczegółowa narracja drobnych zdarzeń, które poprzedzają spotkanie z kochankiem, wszystkie w wyrażającym rutynę imparfait, są wystarczająco prawdopodobne jako iteracje.

Akapit kończy się jednak następującym zdaniem, które, rozpatrywane osobno, uznano by za błąd gramatyczny: „Puis, d'un seul coup d'oeil, la ville apparaissait" (Potem, w mgnieniu oka, ukazywało się miasto; prze-

${ }^{24}$ A. Friedberg, The Virtual Window. From Alberti to Microsoft, Cambridge, MA, 2006. 
kład mój|25. Nagłość implikowana przez wyrażenie przysłówkowe pozostaje w sprzeczności z czasem wyrażającym rutynę. Zwykle sugestia nagłości może przerwać opis rutyny, ale nie odwrotnie. Rutyna, z definicji, nie może niczemu przeszkodzić; brakuje jej temporalnej sprawczości. Zdanie to poprzedzone jest innym, które „wyjaśnia” rzekomą sprzeczność: „... afin de se faire des surprises, elle fermait les yeux" (żeby zrobić sobie niespodziankę, zamykała oczy). Sama się oszukując, Emma desperacko próbuje odzyskać ekscytację związkiem, który, jak możemy się domyślać, ją nudzi. Zamknięcie oczu jest flaubertowskim "spojrzeniem z ukosa” - Emma unika konfrontacji z rzeczywistością. Ponadto jest to przykład tego, jak Flaubert za pomocą subtelnych wskazówek przepowiada tragiczne zakończenie. Próbowałyśmy to wydobyć, rejestrując powtarzające się początki romantycznych spotkań w tym samym pokoju hotelowym i pokazując różnicę pomiędzy rysującymi się na twarzy Emmy początkowym podnieceniem i późniejszą nudą. Użycie jej twarzy jako ekranu projekcji to nasz sposób oddania podmiotowości prozy narracyjnej ${ }^{26}$.

W naszych instalacjach wideo również sięgamy po rozmycia, ruch i radykalne kadrowanie, aby spotęgować wrażenie społecznej izolacji głównej bohaterki, a także jej bycia przedmiotem spojrzenia niewidzialnych innych jako efektu jej własnego spoglądania z ukosa. Staje się to wyraźne na przykład w scenie trzeciej, Wesele, gdzie obserwujący i plotkujący goście traktują Emmę z pogardą (il. 4). Poczucie izolacji, skutkujące samotnością, jest konsekwencją nie tyle jej dosłownego spojrzenia z ukosa, ile unikania dialogu - co na jedno wychodzi. Jej niepewność wyrażona zostaje przez radykalne kadrowanie ujęcia jej twarzy, gdy przygotowuje się do ceremonii ślubnej i pyta swoją fryzjerkę, czy dobrze wygląda.

W Pod górę zarówno mężczyzna ciągnący sanki, jak i postać w zieleni są ledwie czytelnymi, rozmytymi figurami, zbudowanymi z plam farby, a nie precyzyjnych pociągnięć pędzla. Główna postać, łata zielonej i brązowej farby, zamiast twarzy ma pysk, co sprawia, że wygląda jak wilk w ludzkim przebraniu. Jego nogi stapiają się w jedno, wydaje się, że brakuje mu lewej ręki. Jaskrawy strój człowieka po prawej mógł zostać zabarwiony w ten sposób dla efektu kolorystycznego, a nie ze względu na profilmowe okoliczności. Kolorystyczny kontrast między nimi jest tak wyraźny, że odciąga uwagę od narracyinie istot-

${ }^{25}$ Bal dokonuje własnego przekładu książki z francuskiego na angielski. W takim przypadku utrzymywać będę przekład Autorki. Gdzie indziej sięgam po przekład polski: G. Flaubert, Madame Bovary, tłum. A. Micińska, Warszawa 1976 - przyp. tłum.

26 „Błędne” użycie imparfait przez Flauberta było szeroko omawiane w literaturze krytycznej. Zob. cenny zbiór: Gustave Flaubert. Mémoire de la critique, red. D. Philippot, Paris 2006. 

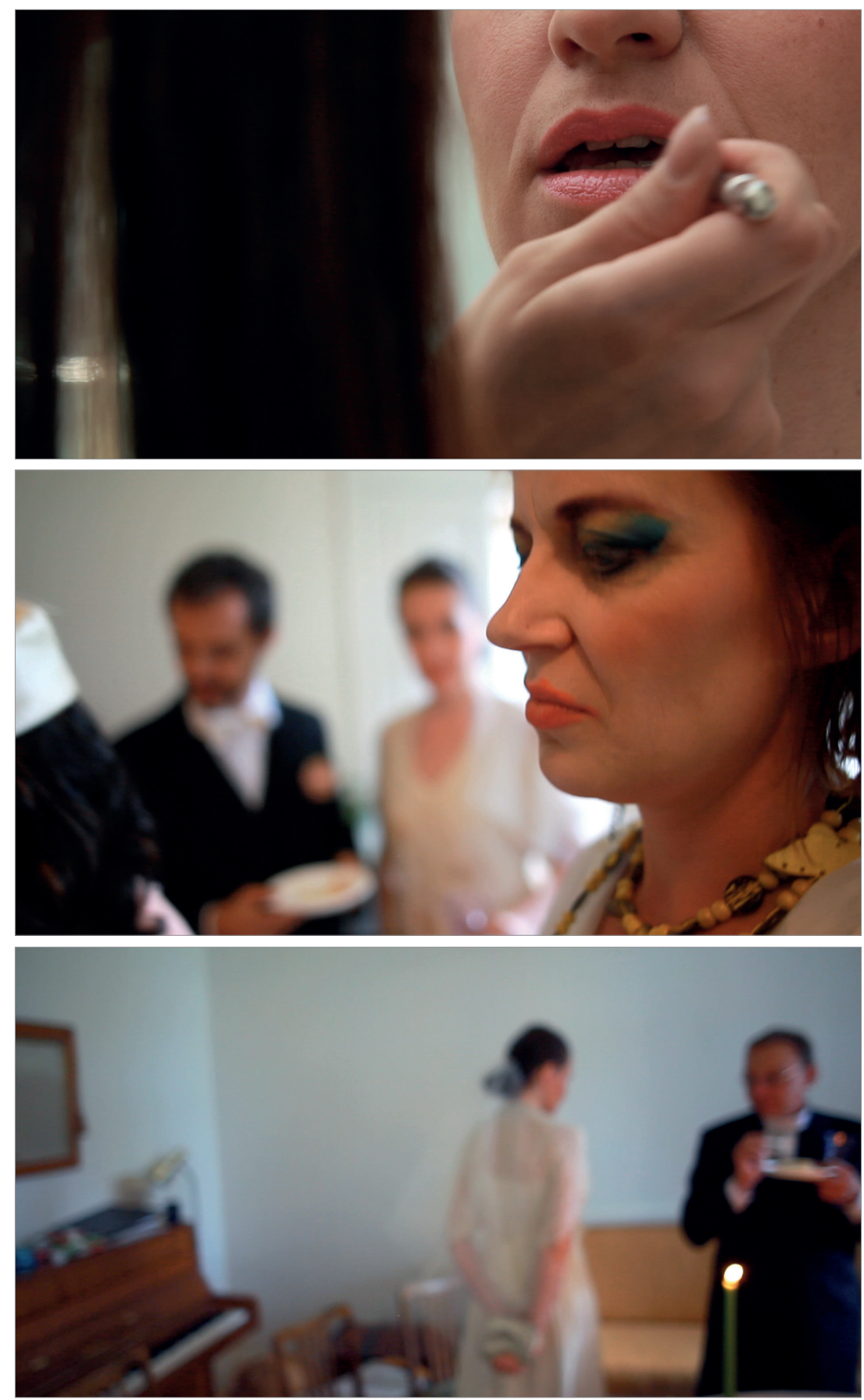

4. Mieke Bal, Michelle Williams Gamaker, Madame B, „Błędy“ w scenie z wesela, kadry z filmu wideo, dzięki uprzejmości Mieke Bal 
nej, wymagającej wysiłku czynności mężczyzny po lewej - czyniąc ten obraz niemal abstrakcyjnym. Abstrakcja, tak jak wszystko, co dotyczy oglądu sztuki, spoczywa w oku widza ${ }^{27}$.

Kolor stanowi jeden $z$ aspektów, który łączy ten obraz z kinem, choć zasadniczo jeszcze nie w czasach Muncha. Artysta użył koloru nie tylko w celu przekroczenia granicy pomiędzy obrazem a wyobrażeniem, ale też, w następstwie tego rozróżnienia, pomiędzy abstrakcją a figuracją. Za pomocą aluzji nadał kolorowi funkcje synestezyjne: sięgając po medium, które służy jedynie zmysłowi wzroku, w swoim malarstwie "dowodził”, że wzrok nigdy nie jest osamotniony; że inne zmysły uczestniczą w percepcji zmysłowej ${ }^{28}$.

Flaubert wykorzystywał dźwięk i kod koloru w celach politycznych. Przykładem może być scena uwiedzenia podczas Comices agricoles, zdaniem Eisensteina - pierwszorzędny przykład montażu. Pochylony służący, który otrzymuje medal za pięćdziesiąt lat służby w pozycji podporządkowania, ubrany jest na niebiesko, biało i czerwono, w niemym proteście prostych ludzi przeciwko kłamstwu wpisanemu we francuską flagę ${ }^{29}$. Istnieje nawet bliższy związek pomiędzy Munchem a Flaubertem, jeśli rozważyć możliwość, o czym piszą niektórzy badacze, że Krzyk ma również „ścieżkę dźwiękową”. Zastosowany tam kolor ma sugerować dźwięk; nie po to, by - jak u Flauberta - kodować kolorem polityczny przekaz, ale by „zakolorować” emocje. Jeśli widzowie „słyszą" krzyk w kolorach, to w obu przypadkach mamy do czynienia z synestetycznie działającymi znakami, które przekraczają odpowiednie im media. Porównanie, lub ratowanie jednego przez drugie, ujawnia zarówno podobieństwo - synestetyczne oznaczanie, jak i różnice - użycie koloru, polityczne u Flauberta, emocjonalne u Muncha.

27 Realistycznie patrząc, kolor stroju może odnosi się do oliwkowej barwy ubrań rybaków. Munch namalował rybaka w żółtawym ubraniu w roku 1902, również wyrwanego z kontekstu, przedstawionego na zielonym tle. Za tę informację dziękuję Ute Kuhlemann Falck.

${ }^{28}$ Jak pokazała książka pod redakcją Giovannny Fossati, we wczesnym kinie w rzeczywistości użycie koloru było szerokie (Fantasia of Color in Early Cinema, red. G. Fossati, Amsterdam 2015). Badacze omawiali Muncha użycie koloru w celu wyrażenia dźwięku $\mathrm{w}$ Krzyku. Zob. I. Ydstie, Painting is what the brain perceives through the filter of the eye, w: Edvard Munch: The Modern Eye, red. A. Lampe, C. Cheroux, London 2012, zwłaszcza s. 259. Kolor jest taże ważnym elementem w szczegółowej analizie Jaya A. Clarke’a obrazu Chore dziecko, namalowanego w latach 1885-1888 (J.A. Clarke, Originality and Repetition in Edvard Munch's The Sick Child, w: Edvard Munch: An Anthology, red. E. Mørstad, Oslo 2006. Na temat relacji koloru i abstrakcji zob. ostatni rozdział M. Bal, Endless Andness: The Politics of Abstraction According to Ann Veronica Janssens, London 2013.

29 P.-M. de Biasi, Gustave Flaubert. Une manière spéciale de vivre, Paris 2009, s. 245. 
W sztuce Muncha momenty, w których figuracja jest zaburzona, niemal wymazana, przez abstrakcję, stanowią klucz do zrozumienia wieloznaczności, która leży u podstaw jego polityczności i politycznej pozycji. Często ograniczenie figuracji za pomocą zamazania, opróżnienia czy braku ostrości w przedstawieniu oczu staje się miejscem oporu wobec nieubłaganie trwałego romantyzmu, który został przedstawiony; nie ukształtowany, lecz pozostawiony w bezkształtnej postaci. Miejsca niejasności w obrazach ukazujących na przykład sceny miłosne, wskazują na inną stronę figuracji miłości. A zatem od fizycznego ruchu dzieło wiedzie nas ku rozważeniu ruchu jako perswazji, ale nie tylko intelektualnie; porusza nas w kierunku zmiany, działania albo sprzeciwu.

Munch oznajmia, że linia dzieląca figurację i abstrakcję nie istnieje; że to ideologia, która nas usidla w binarnej opozycji, podczas gdy istnieje bardziej subtelne i złożone kontinuum. Podczas gdy cechy Galopującego konia są wyraźnie rozpoznawalne, a oko zaznacza wściekłość biegnącego na złamanie karku zwierzęcia, powożący i dzieci po prawej znów stanowią ledwo czytelne zamazane plamy. Niemniej, zwracająca się w stronę widza, wyglądająca jak dziecko postać - kilka śladów czerwieni na białej plamie oznaczających jej rysy twarzy - wygląda na przerażoną. Dlaczego dostrzegamy to przerażenie w owych nieokreślonych plamkach? Munch „twierdzi”, że widzialność nie zależy od ostrości.

Obaj artyści w swojej sztuce wykorzystują „błędy” w celu wzmocnienia samego medium. Rozmycie i zróżnicowanie głębi ostrości podpowiada nam, że nie oglądamy transparentnego przedstawienia profilmowej rzeczywistości, lecz wykonany obraz. Podobnie nierównomierna aplikacja farby, którą Munch opanował mistrzowsko, ciągle uświadamia nam, że to, co widzimy, nie jest jakąś sytuacją z rzeczywistego życia, ale czymś, co, z uwagi na swoją dwoistość, jest znacznie bardziej niepokojące. Zamiast unikać realistycznej iluzji poprzez całkowitą eliminację figuracji i zwrócić się ku czystej abstrakcji, artysta ciągle utrzymuje figurację, a jednocześnie - wykorzystując w tym celu abstrakcję - wyraźnie demonstruje, jak jest ona skonstruowana. Błędy mogą być pośrednikiem pomiędzy fałszywą opozycją figuracji i abstrakcji. Bjerke postrzega abstrakcję jako rezultat „swobodnego, malarskiego potraktowania koloru, gdzie odniesienia do konkretnych obiektów niemal ulegają rozpuszczeniu" ${ }^{\prime 30}$.

Nie sięgając po słowo „abstrakcyiny”, historyk sztuki Magne Bruteig przedstawia piękną analizę małego rysunku pt. Wypadek, który ceni właśnie dlatego, że jest on „mniej udany jako czysta dokumentacja, jeśli klarowność

${ }^{30}$ Bjerke, Style and Technique, s. 52. 
miałaby być tym, co się liczy". Opisuje ową kartę z rysunkiem w kategoriach dezorientacji i gęstości, zakreskowanych fragmentów i nieobecności ciemności tam, gdzie można by się jej spodziewać31. Konkluduje, sięgając po kategorie przypominające Bjerkego interpretację błysku w monoklu: „Nierealne światło stanowi obiekt silnie koncentrujący spojrzenie, który przyciąga naszą uwagę jak magnes"32. Ponownie szczegół obrazu, a także przedstawienia [depiction], wychodzą na plan pierwszy, by oddziałać na widza tam, gdzie ów szczegół oddziałuje dzięki nieobecności tego, czego byśmy się spodziewali.

Historyk sztuki Nils Messel przypomina, że „błędy” zawsze stanowiły element strategii Muncha, a także cel ataku konserwatywnej krytyki. Pisze: „W sztuce Muncha naturalistyczny krytyk dostrzegał i cenił to, co Frits Thaulow kiedyś określił jako «zadziwiającą courage de défauts [śmiałość popełniania błędów]”", to znaczy „jego odważną akceptację faktu, że sztuka nie ma kopiować natury, ale oddawać jej wysoce osobistą, subiektywną impresję" ${ }^{\prime \prime 3}$. Zamiast słowa „impresja” użyłabym tu słowa "fuzja”, jak w sformułowaniu „subiektywna fuzja”.

\section{RUCH I PAMIEcĆ}

W czasach Muncha istniało wielkie zainteresowanie przepływami energii, pomiędzy ruchem rzeczywistym a ruchem psychicznym, emocjonalnym. Christoph Asendorf wskazuje na trzy modusy uwidaczniania przepływu energii: „linie siły, przedstawienie aur i podział piktorialnej płaszczyzny, figury i tła na pasma" ${ }^{34}$. Linie siły, pisze Asendorf, to "transponowane gesty, wyrazy witalności. A zatem są one wpisane jako wyrazy stanów emocjonalnych $[\ldots]^{\prime \prime 35}$.

W Galopującym koniu Muncha nie widzimy twarzy drugiego dziecka jedynie jego podniesione ręce sugerują strach. To jest „transpozycja gestu”. Poprzez zwrot tej dwójki dzieci w przeciwnych kierunkach, jednego frontalnie, drugiego tyłem do widza, artysta wydaje się mówić, że całe ciało uczest-

${ }^{31}$ M. Brutejg, Unpainted Drawings, w: Munch Becoming 'Munch': Artistic Strategies 1880-1892, red. I. Ydstie, M.B. Guleng, Oslo 2008, s. 67.

32 Ibidem.

${ }^{33}$ N. Messel, Edvard Munch and His Critics in the 1880s, w: Munch Becoming 'Munch', s. 166.

${ }^{34} \mathrm{Ch}$. Asendorf, Power, Instinct, Will: Munch's energetic World Theatre in the Context of Fin de Siècle, w: Edvard Munch: Theme and Variation, red. K.A. Schröder, A. Hoerschelmann, Vienna 2003, s. 87.

${ }^{35}$ Ibidem. 
niczy w doświadczeniu i wynikającym z niego wyrażaniu strachu. Element strachu w obrazie odnosi fizyczny ruch konia do emocjonalnego ruchu dzieci. Ponadto ich przerażenie możemy sobie wyobrazić, dopiero gdy staniemy pomiędzy nimi, dokładnie w połowie wysokości obrazu. Spłaszczona relacja owych dwóch przestraszonych postaci jest zatem "instrukcją użytkowania” spojrzenia. Musimy przenieść się do wnętrza obrazu.

Co te trzy obrazy Muncha mówią nam o ruchu w nieruchomym obrazie w relacji z czasem i czasem gramatycznym? Dotyczy to temporalnego dialogu pomiędzy teraźniejszością i przeszłością, który ustanawia pamięć. Problem ten zostaje również podniesiony w powieści Flauberta. Jej pierwsze zdanie to: „Odrabialiśmy lekcje, kiedy wszedł dyrektor, a za nim nowy ubrany po miejsku i chłopak do posług z dużym pulpitem" ${ }^{\prime 36}$.

Po kilku pierwszych stronach, pierwsza osoba liczby mnogiej „my” powraca kilka razy, po raz ostatni w zdaniu: „Nikt z nas nie byłby w stanie dziś przywołać żadnego związanego z nim wspomnienia” [Il serai maintenant impossible à aucun de nous de se rien rappeler de lui]. Uderzające jest, że przysłówek maintenant (dziś, teraz) odciąga zbiorową pierwszą osobę od przeszłości w teraźniejszość, co pozostaje w symetrii z zakończeniem powieści. Jednak niemożliwość pamiętania pozostaje w konflikcie $z$ uprzednim opisem: precyzyjnym, szczegółowym i zawierającym cytowane przemowy. Stoi to w sprzeczności z podwójną negacją: nikt, ktokolwiek z obecnej grupy, z nas, nie może przypomnieć sobie czegokolwiek - a jednak powieść szczegółowo opowiada owo niemożliwe wspomnienie. To jest właśnie sztuczka fikcji - w literaturze, malarstwie i wideo ${ }^{37}$.

Skoro wszystkie dowody wskazują na obecność narratora, stanowcze wyparcie się wiedzy musi służyć jakiemuś innemu celowi. Użycie "nous” [my] musi być związane $z$ niemożliwością zapamiętania, zwyczajnością nowego szkolnego kolegi. Narrator jest świadkiem, ale ów bohater jest tak zwyczajny, że mógłby być kimkolwiek i zostać łatwo przeoczony. Ten status everymana, a także historia, która rozpoczyna się jego opisem, czyni z niego „Everymana” alegorycznego, a zarazem tak realnego jak każdy. Pozycja narratora jako świadka pozwala mu dokonać radykalnej krytyki jego środowiska - owego tu i teraz - a także ciągle i kreatywnie zmieniać swoją pozycję od identyfikacji z główną bohaterką Emmą po niemal cyniczną pozycję outsidera.

${ }^{36}$ Flaubert, Madame Bovary, s. 32.

37 Zob. szczegółową analizę owego „nous” (my) w powieści: F. González, La scène originaire de Madame Bovary, avant-propos de Charles Grivel, Oviedo 1999; a także De Biasi, Gustave Flaubert, s. 151-68. 
"Nous" sugeruje, że tym, co narrator jako świadek zaraz opowie, będzie historia pochodząca $z$ realnego życia i że dzięki temu "teraz" w drugim zdaniu w pierwszej osobie liczby mnogiej jest ona współczesna. Ten dyskurs „nas” w tu-i-teraz to realizm Flauberta. Idea „profilmowości”, wraz z Foucaultowską komplikacją (nie)widzialności, pomaga nam ów realizm zrozumieć. Nie jest on związany ani z binarną opozycją fikcja-rzeczywistość, ani z wiernym opisem - ponieważ „błędy” są potrzebne w celu pokazania tego, co robi artysta. Narrator może być świadkiem, ale rzekoma obiektywność realistycznej fikcji nie jest zagwarantowana.

Ostrzegam: realizm spoczywa gdzie indziej - w tobie, czytelniku; nie będzie łatwo odseparować się od wpadek i nieszczęść, które nastąpią. Funkcja świadczenia jest kluczowa. Jest to pierwszy powód, dla którego zdecydowałyśmy się przekształcić powieść w serię immersyjnych instalacji. Próbowałyśmy zatem stworzyć „nous” dla naszej teraźniejszości, porywając - czy raczej cytując - Flauberta „maintenant”. Projekt ten stanowi próbę zrobienia tego również z Munchem, który w słynnych słowach zadeklarował: „Maluję nie to, co widzę, ale to, co widziałem" - malował swoje wspomnienia. A dzięki jego obrazom możemy teraz stanąć pomiędzy owymi przerażonymi dziećmi i przypomnieć sobie ich strach, tak jakby był naszym strachem - teraz ${ }^{38}$.

Tą wypowiedzią Munch pokazuje swoją „obrazową inteligencję” - swą umiejętność artykulacji w adekwatnych filozoficznych kategoriach tego, co ma znaczenie w sztuce. Chciałabym rozwinąć to krótkie stwierdzenie. Zależy nam na sztuce $z$ uwagi na jej performatywność - jej moc, by wywierać na nas wpływ, a nawet nas zmieniać. Ale co właściwie ona robi i w jakich wymiarach egzystencjalnych? Wywodząc się z drugiego, zadanego na początku pytania, "Co sprawia, że obraz porusza?”, wyrażenie „sztuka porusza” zreasumowana w kwalifikatorze „kinowy” łączy refleksję dotyczącą performatywności sztuki opartej na jej zakotwiczeniu w przestrzeni i czasie oraz sposobie, w jaki działa swoją formą. Sztuka jest przestrzennie performatywna, ponieważ sztuka wizualna istnieje i funkcjonuje w przestrzeni, i dlatego także wpływa na przestrzeń, która ją otacza, co ma z kolei wpływ na ludzi, którzy ową przestrzeń zamieszkują. Nawet na wystawie nieruchomych obrazów, takich jak obrazy malarskie i rysunki, a zwłaszcza rzeźby, widzowie spacerują dookoła i widzą obrazy w (należącym do nich) ruchu. Wymiary i skala dzieł ma „żywy” wpływ na ogląd. Dlatego w tej książce uwzględniono wymiary w podpisach. I jeśli [dzieła] oddziałują na widzów - innymi słowy, widzowie są przez nie porusze-

${ }^{38}$ Munch napisał to w niewielkiej publikacji zawierającej dewizy i wypowiedzi dotyczące sztuki (1928?). Tych dwóch artystów łączy wyjątkowy modus realizm, który nie jest mimetyczny, ale oddziałuje na rzeczywistość na nieprzedstawiające sposoby. 
ni - dzieje się to w ruchu w przestrzeni. Jest to aspekt wspólny wszystkim obrazom, nawet jeśli instalacja wideo czyni to afektywne oddziaływanie bardziej konkretnym niż inne media. Przestrzeń ma się do sztuk wizualnych tak, jak dźwięk do literatury, co podkreślone jest u Flauberta przez uważną orkiestrację dźwiękowych akcentów ${ }^{39}$.

Obrazy poruszają się również w czasie. Dzieła nie tylko wyłaniają się z czasu (zwykle przeszłości) i docierają z przeszłości w naszą teraźniejszość. One również funkcjonują w czasie - momencie i trwaniu - spotkania, w teraźniejszości, i ukierunkowują nas ku przyszłości. A wygląd dzieła, jego forma, oddziałują na nas także emocjonalnie. Te różne rodzaje ruchu dzieła współgrają ze sobą niezależnie od tego, czy mowa o nieruchomym, czy ruchomym obrazie. Chodzi tu o ujęcie sztuki, która zakotwiczona jest w naturze percepcji i sposobie, w jaki pamięć ma w niej udział.

Stawką jest związek pomiędzy nieruchomym i ruchomym obrazem. Trzy obrazy Muncha pokazały, że polega on na żywej dyskusji prowadzonej za pomocą malarstwa. Zarówno w malarstwie, jak i kinie związek ten zostaje odzwierciedlony i poddany refleksji w postaci autorefleksji; artyści pracujący w odmiennych mediach pożyczają od siebie, aby wzmocnić potencjał swojego własnego medium. Malarstwo i kino łączy fundamentalna własność obrazów - ich bycie przedmiotem percepcji. Tu sięgam po współczesnego Munchowi francuskiego filozofa Henriego Bergsona (1859-1941), który odcisnął trwałe piętno nie tylko na filozofii, ale też, w bardziej ogólnym sensie, na kulturowej myśli i analizie. Spuścizna Bergsona miała fundamentalne znaczenie dla studiów nad filmem i odwrotnie - kino stało się anachronicznym modelem dla innych wizualnych i audiowizualnych przejawów kultury. Demonstrują to owe trzy omówione tutaj obrazy ${ }^{40}$.

39 To właśnie dlatego żaden przekład nie jest w stanie zastąpić tekstu Flauberta, jak ostatnio znów twierdził Michael Fried (M. Fried, Flaubert's 'Gueuloir': On Madame Bovary and 'Salammbô, New Haven-London 2012, 1-2). Zapożyczam sformułowanie „piktorialna inteligencja" z książki poświęconej Tiepolowi: S. Alpers, M. Baxandall, Tiepolo and the Pictorial Intelligence, New Haven-London 1994. Zob. klarowny przegląd pojęcia performatywności: J. Culler, The Performative, w: idem, The Literary in Theory, Stanford, CA, 2007, s. 137-165; zob. również inne opracowania: J.L. Austin, How to Do Things with Words, Cambridge, MA, 1975 - w kwestii początkowego sformułowania tego pojęcia; zob. J. Derrida, Signature, Event, Context, w: idem, Limited Inc., tłum. S. Weber, Evanston, IL, 1988, s. 1-23, który je poszerza; oraz J. Butler, Bodies that Matter: On the Discursive Limits of 'Sex', New York 1993; eadem, Excitable Speech: A Politics of the Performative, New York 1997 - na temat teoretyzacji politycznej aktualności performatywności.

40 Bergson bardzo głęboko oddziałał na Gilles'a Deleuze’a (1925-1995), który miał się stać ważnym filozofem kultury naszego czasu, w szczególności za sprawą swojej wizji kina. W jego publikacjach, włączając w to słynną książkę o kinie, reaktywował prace Bergsona. 
Książka Bergsona Materia i pamięć z roku 1896 rozpoczyna się tezą na temat percepcji. Bergson twierdzi, że percepcja nie jest konstrukcja, za jaką ją uważaliśmy w postrealistycznej epoce, lecz selekcją. Podmiot dokonuje tej selekcji ze względu na swoje własne zainteresowania. Percepcja, zdaniem Bergsona, jest aktem ciała i dla ciała, jako że jest ono ulokowane pośród rzeczy, z których może dokonywać wyboru. To dlatego faktura, kolor i wymiary mają znaczenie w takim stopniu jak figury, przestrzeń i perspektywa. Wprowadza ona widza również w orbitę tego, czym jest sztuka, a zatem kwestionuje ideę autonomii sztuki ${ }^{41}$.

Percepcja jest aktem teraźniejszości. Jednak gdyby nie udział pamięci, mogłoby to zakładać naiwny prezentyzm - zawężenie czasu do krótkiego momentu teraz, temporalnego selfie. Wydarzając się w teraźniejszości, percepcja związana jest z pamięcią. Bez pamięci część widzialnego świata, którą akurat postrzegamy, nie miałaby sensu jako przedmiot naszego wyboru. To właśnie powiedział Munch w cytowanym zdaniu. Nie potrzebowałby nawet zaprzeczenia („Maluję nie to, co widzę"), ale łącząc dwie temporalności, mógł był napisać: „Maluję to, co widzę, a więc to, co pamiętam”. Ponieważ to zainteresowanie podmiotu stanowi motywację do selekcji, czyli percepcji, obraz percepcyjny, który nie jest nasycony obrazami pamięciowymi, nie miałby sensu. Nie miałby też zmysłowego oddziaływania, ponieważ postrzegamy za pomo$c q$ - a także dla - ciała. To dlatego ciało także pamięta. Pod koniec książki Bergson pisze, w jaki sposób pamięć uczestniczy w percepcji. To uczestnictwo uwzględnia subiektywną naturę percepcji, nawet jeśli rzeczy, które postrzegamy, istnieją poza naszą świadomością. Pisze on tak: „Natomiast w konkretnej percepcji interweniuje pamięć, a subiektywność jakości zmysłowych polega właśnie na tym, że nasza świadomość, która przede wszystkim jest pamięcią, przedłuża wielość chwil, jedne w drugich, by dokonać ich kontrakcji w jakiejś jedynej intuicji" ${ }^{42}$.

Deleuze na temat Bergsona zob. G. Deleuze, Bergsonizm, tłum. P. Mrówczyński, Warszawa 1999; na temat kina: G. Deleuze, Kino. 1. Obraz-ruch, 2. Obraz-czas, tłum. J. Margański, Gdańsk 2009. Przystępne wprowadzenie do Deleuze'a filozofii kina w: P. Marrati, Gilles Deleuze: Cinema and Philosophy, tłum. A. Hartz, Baltimore 2008.

${ }^{41}$ H. Bergson, Materia i pamięć, tłum. R.J. Weksler-Waszkinel, Kraków 2006. Część tego omówienia idei Bergsona pochodzi ze wstępu do mojej książki poświęconej wideoinstalacji: M. Bal, Thinking in Film. The Politics of Video Installation According to Eija-Liisa Ahtila, London-New York 2013.

${ }^{42}$ Bergson, Materia i pamięć, s. 173. [Tutaj pojawia się problem z przekładem i związana z tym konieczność modyfikacji polskiego tłumaczenia. Zarówno we francuskim oryginale, jak i angielskim przekładzie, z którego korzysta Bal, pojawia się słowo, odpowiednio, contracter i contracting, które można przełożyć jako ściągnięcie, skurczenie, zawężenie, 
To również wyjaśnia, dlaczego Bergson nalegał tak bardzo na trwanie. Jak napisał Deleuze w Bergsonizmie, „Bergsonowskie trwanie definiuje się ostatecznie w mniejszym stopniu przez następstwo niż przez współistnienie ${ }^{\prime 43}$. Przestrzenna niespójność Robotników Muncha podkreśla mnogość, która zbliża się do tej kontrakcji, ale jeszcze jej nie osiągnęła. Mnogość kinowych „ujęć" stanowi narzędzie, którego użył artysta, aby zdenaturalizować automatyzm owej kontrakcji.

Według artysty i krytyka Gianfranca Bruno, niektóre z fotografii Muncha, oparte na podwójnej ekspozycji, stanowią eksperymenty zmierzające do odpakowania tego właśnie współistnienia pomiędzy teraźniejszością a przeszłością. Komentując fotografię Muncha, przedstawiającą ściany domu, gdzie zmarła matka artysty, Bruno pisze, że „fotografia ta pokazuje kontury ścian $\mathrm{w}$ podwojonym obrazie $\mathrm{z}$ nadzwyczajnym efektem udręczonego "déplacement»"44. Kilka stron dalej pisze: „Fotografia ukazała, że starodawne domostwo realnego i wyobrażeniowego mogło zostać zreprodukowane i że mogła skupić się w nim inna emocjonalna aktualność" ${ }^{\prime 4}$. Bruno zbliża się do Deleuze'a za pomocą słowa „skupić” [converge], a do Bergsona - „emocjonalną aktualnością" w odniesieniu do przeszłości. Konkluduje, że Munch w swojej fotografii zastosował $\mathrm{i}$ „przyswoił sobie technikę filmowania"46.

\section{CZAS, PRZESTRZEŃ I FORMA}

Ta współegzystencja różnych momentów (tych wspomnień) ma aspekt przestrzenny. Jest ona czasoprzestrzenią [timespace]. I owa czasoprzestrzeń otrzymuje swój kształt w sztuce. Powyżej wskazałam aspekty, które sprawiają, że czas zostaje uaktywniony (przycięte ramię), a przestrzeń staje się heterogeniczna (fiord i wzgórze). Czasoprzestrzeń zyskuje być może największą wizualną konkretyzację w wideoinstalacji. Tam jednoczesna obecność licznych ekranów - a więc i jednoczesny ruch na nich - ucieleśnia współistnienie trwania i różnych momentów. Stanowi to widzialny przykład Berg-

czy, bardziej technicznie - kontrakcję. W polskim tłumaczeniu ostatni człon tego zdania brzmi: „by je zawrzeć w jakiejś jedynej intuicji”, co brzmi stylistycznie lepiej, lecz, po pierwsze, gubi znaczeniową dynamikę oryginalnego słowa, a po drugie - nie pozwala na konsekwentny przekład słowa contraction, do którego Bal kilkukrotnie powraca w dalszej części swojego tekstu - przyp. tłum.].

${ }^{43}$ Deleuze, Bergsonizm, s. 57 (wyróżnienie dodane).

${ }^{44}$ G. Bruno, The Poetry of the Imaginary, w: Munch, Milan 1986, s. 43.

45 Ibidem, s. 46.

46 Ibidem. 
sonowskiej mnogości momentów ściągniętych [contracted] w „pojedynczą intuicję".

W tym sensie, jak dowodziła Pepita Hesselberth, wideoinstalacja jest najbardziej ekstremalną manifestacją kinowości. Leevi Haapala również wskazuje, że: „wideoinstalacja złożona z kilku ekranów musi być postrzegana jako przestrzeń dla czystego ruchu śladu” ${ }^{47}$. „Ślad” to odpowiednie słowo; ponieważ ślad ucieleśnia również splot przeszłości i teraźniejszości. Ponadto każde pociągnięcie pędzla w obrazie stanowi ślad gestu, poruszanego decyzją artysty. Wreszcie termin „ślad" ma tu sugerować, że błędy także muszą być postrzegane jak ślady, jako dowód ruchu w czasie i przestrzeni.

Dostrzegamy wspólną artykulację przestrzeni i czasu poprzez ruch. Razem są one jedynie możliwe do zrozumienia i funkcjonalne w związku z podmiotem percepcji. Zdaniem Bergsona, przestrzeń nie jest geometryczna, czego dowodziła wizualnie renesansowa perspektywa: w rezultacie nie jest ona ani mierzalna, ani identyczna dla każdego, kto ją postrzega. Natomiast nasze poczucie przestrzeni rozwija się zgodnie $z$ „naturalnym odczuciem” - z podmiotem jako jego punktem początkowym. To naturalne uczucie jest heterogeniczne i różni się dla każdego, w zależności od tego, gdzie on/a się znajduje. Trzy obrazy Muncha poświęcone są eksploracji alternatyw dla zhomogenizowanej przestrzeni. Wielorakie perspektywy Robotników, ekscentryczna wysokość i trzy różne kąty oglądu w Pod górę oraz sposób, w jaki zaśnieżona droga znika w oddali w Galopującym koniu: wszystkie trzy stanowią przykład przestrzennej heterogeniczności. Skupiają uwagę na przestrzennie problematycznym pierwszym planie w celu podkreślenia zdradliwej natury perspektywicznej koncepcji widzenia.

W Czasie i wolnej woli Bergson nazywa ową przestrzeń „ekstensywnością", postrzegając ją jako coś, co emanuje $z$ podmiotu ${ }^{48}$. W trzech kinowych obrazach Muncha przestrzeń jest właśnie taka: heterogeniczna, mnoga, zarówno fikcyjna, jak i rzeczywista, zarówno subiektywna, jak i ekstensywna, a zatem deiktyczna. To dlatego ucieleśniają relacyjny aspekt ich doświadczenia; dlatego - w całej swojej malarskości - zmuszają do „myślenia filmem” [thinking in film], równorzędnie podkreślając filmowy, określony przez czas, aspekt trwania obrazów oraz przestrzenny, ekstensywny aspekt przyimka „ $\mathrm{w}^{\prime \prime}$

${ }^{47}$ Hesselberth, Cinematic Chronotopes; L. Happala, A Divided Sentence, a Split Viewer: Observations on Distal Sensuousness in Eija-Liisa Ahtila's Moving Image Installations, w: Eija-Liisa Ahtila: Parallel Worlds, red. L. Esssling, Stockholm 2012, s. 171 (wyróżnienie dodane). Choć ja sama użyłabym „śladu” w liczbie mnogiej.

${ }^{48}$ H. Bergson, Time and Free Will: An Essay on the Immediate Data of Consciousness, tłum. F.L. Pogson, New York 1960 [1889]. To samo odnosi się do czasu. Tak jak bergsonowska przestrzeń, trwania nie można ani podzielić, ani zmierzyć. 
[in] ${ }^{49}$. To właśnie tak przestrzenie instalacji stają się przestrzeniami kontaktu, w sensie „stref kontaktu” Mary-Louise Pratt ${ }^{50}$.

Działanie sztuki wizualnej, fakt, że dzieła sztuki wpływają na nas, stanowi konsekwencję heterogeniczności i jednocześnie subiektywności czasoprzestrzeni. Bergson żył w tym samym czasie co Munch. Jeśliby się spotkali, mogliby wejść we wspaniały dialog. Munch mógłby wnieść do niego wizję związku pomiędzy figuracją a abstrakcją, dla której Bergsona spojrzenie na materię i pamięć dostarczyłoby filozoficznej podstawy. Podobnie byłoby z Deleuze'a ujęciem abstrakcji - nie jako braku formy, ale obietnicy lub potencjalności formy; jej możliwości. Znakomicie wpisując się w stylistykę modernistycznego malarstwa tamtego czasu, swobodne ślady pociągnięć pędzla i na wpół abstrakcyjne kształty w tych trzech obrazach - zwłaszcza w Pod góre mają również związek z pamięcią. Bergson sugeruje, że życie w trwaniu stanowi formę gromadzenia [gathering]: każdej chwili towarzyszy pamięć chwil poprzednich, w niechronologicznym porządku ${ }^{51}$.

Plamki farby również można postrzegać jako takie gromadzenie. Formalnie owe plamki ledwie trzymają się razem. Zastanówcie się tylko nad "twarzą" przerażonego dziecka w Galopującym koniu, nad jej białą plamą i czerwonymi punktami. Jednakże ostatecznie owe plamki znakomicie prezentują swoją treść. Na przykład odnosi się to w Pod górę do: wysiłku, zimna, śniegu, ludzi, wysokości, sanek. W Galopujacym koniu dodalibyśmy: strach, prędkość, dudniący hałas. Wszystkie te elementy „zgromadzone” razem konstytuują znaczenie obrazu. Jest to możliwe, ponieważ wszyscy pamiętamy, że widzieliśmy nie te rzeczy, ale rzeczy takie jak te: biegnące zwierzęta albo ludzi, przerażające widoki i odczucia; jaskrawie zielone ubranie lub takowe $\mathrm{w}$ innym jaskrawym kolorze. Pamięć działa w ten sposób, ponieważ stanowi materialną, cielesną praktykę. To coś, co robimy; składa się z aktów, a nie impresji, które przychodzą z zewnątrz do pasywnych ludzi. Akty pamięci odbywają się w teraźniejszości. Dokładnie tak jak percepcja.

49 Pożyczyłam sformułowanie "thinking in film” z wywiadu z Eiją-Liisą Ahtilą. Zob. Ch. Iles, Thinking in Film: Eija-Liisa Ahtila in Conversation with Chrissie Iles, „Parkett” 2003, 68, s. 58-64. Użyłam go również w tytule mojej książki poświęconej twórczości Ahtili [Owo „w" odnosi się do „in” we frazie „thinking in film”, ginie ono w przekładzie na język polski - przyp. tłum.].

50 M.-L. Pratt, Imperial Eyes: Travel Writing and Transculturation, London 1992 [przypis dodany przez tłumacza].

${ }^{51}$ Na temat Deleuze'a wizji abstrakcji zob. J. Rajchman, Another View of Abstraction, „Journal of Philosophy and the Visual Arts” 1995, 5(16), s. 16-25. Uwagi na temat abstrakcji u Muncha pojawiać się będą w całej mojej książce [z której pochodzi przekładany tekst - przyp. tłum.]. 
Percepcja, tak jak pamięć, wiąże się z materialnością obiektów i ludzkiego ciała. Bergson uważa ciało za byt materialny, a więc percepcję - za materialną praktykę. I, biorąc pod uwagę jego przekonanie o nierozdzielności czasu i przestrzeni, obraz jest $z$ definicji w ruchu. Zatem, wszystkie obrazy, właczajac w to "nieruchome" [still] obrazy, poruszaja (się). Ta poruszająca (się) jakość nie ogranicza się ani do obrazów, ani do medium. Nawet radykalnie abstrakcyjne i zdecydowanie nieruchome obrazy poruszają (się). Pozostaje nam jeszcze kwestia politycznego efektu obrazów, ich potencjału, by poruszyć nas do działania.

\section{SZTUKA, KTÓRA PORUSZA NAS POLITYCZNIE}

Polityczny wymiar Robotników jest wyraźny i oczywisty. Eggum, jeden z badaczy, którzy zauważyli przestrzenną niezborność „ujęć” w Robotnikach w drodze do domu, określa ją w politycznych kategoriach, pisząc: „zbiór poważnych, nieruchomych twarzy mężczyzn, którzy nie chcą, by ich zatrzymywać, nieustępliwa masa krocząca ku nowej epoce". Następnie łączy polityczny przekaz z medium filmu: „Zarówno perspektywa ujęcia motywu, jak i kształt środkowej postaci, całkowicie pozbawiony proporcji, z jego silnym torsem i lśniącą twarzą, sugerują skojarzenia $z$ - i są nim prawdopodobnie inspirowane - ruchem i zniekształceniami filmu"52.

Woll w jeszcze bardziej bezpośredni sposób łączy ten obraz z historycznymi wydarzeniami, takimi jak rewolucja październikowa. W swoim ważnym studium „monumentalnych projektów” pisze: „Polityczne wydarzenia ostatnich lat jasno pokazały, że robotnicy stanowili [...] siłę, z którą należało się liczyć" ${ }^{\prime \prime 3}$. Wcześniej podsumowuje ona swoje podejście do tego obrazu jako jednego z grupy prac: „Robotnicy w owych obrazach są przede wszystkim przedstawicielami grupy społecznej, klasy" ${ }^{\prime \prime 4}$.

Bezpośrednie powiązanie z politycznymi wydarzeniami, choć dość przekonujące, nie jest niezbędnym warunkiem, by uważać sztukę za społecznie i politycznie ważną. Sztukę, która działa w ramach, oddziałuje na albo czyni aluzję do historycznych wydarzeń politycznych, można zakwalifikować jako to, co Hernández-Navarro nazywa "sztuką historii", w inteligentnym odwróceniu powszechnego terminu „historia sztuki”. Zamienia w ten sposób dyscyplinę w gatunek. To cenna interwencja nie tylko w niekiedy nieco zbyt sztywne stosowanie etykiet gatunkowych, ale także mająca na celu podtrzymanie

52 Ibidem, s. 253-254.

53 Woll, Now It is the Time of the Workers, s. 72.

54 Ibidem, s. 66. 
dyscypliny historii sztuki jako istotnej i relatywnej. Na tyle, na ile interpretacja Woll jest przekonująca, Robotnicy wpisują się w nowo wymyślony przez Hernandeza gatunek ${ }^{55}$.

Chcę jednak konceptualnie zarówno poszerzyć, jak i zawęzić to, co sprawia, że sztuka jest polityczna, niezależnie od tego, czy jest związana z historycznymi wydarzeniami lub czy je reprezentuje. W tej argumentacji lepszymi przykładami są obrazy pustki, ponieważ są one polityczne w mniej oczywisty sposób. Refleksja ta każe mi po raz ostatni powrócić do Bergsona. W jego koncepcji jest jeszcze jeden rodzaj ruchu. W roku 1907 ukuł pojęcie „ewolucji twórczej" ${ }^{\prime 56}$. Użył go w celu opisania rodzaju ruchu, który jest zarówno emocjonalny, jak i społeczny, a przez to staje się polityczny. Pojawia się on, gdy rozumienie i działanie ulegają zespoleniu. Ten czwarty bergsonowski ruch, który generuje gotowość do działania, leży w samym sercu politycznego potencjału obrazu, pod warunkiem, że działa on wspólnie z pozostałymi trzema.

Wideoinstalacja może stworzyć dosłowne ucieleśnienie tego potencjału w fikcyinej przestrzeni, która - z pomocą widza - może stać się polityczną, demokratyczną przestrzenią. Kinowość pomaga wyartykułować ruch obrazów, malarstwo pomaga uaktywnić jego zależność od tworzywa [support], a literatura zwraca język przeciwko sobie za pomocą niewspółmiernych wyborów słów i „błędnej” gramatyki. Właśnie w ten sposób wideoinstalacja może pomóc w zrozumieniu tego, jak sztuka w ogóle, włączając w to nieruchome obrazy, takie jak obrazy malarskie, może być niebywale skuteczna w osiąganiu politycznych celów poprzez jej fundamentalnie poruszającą (się) jakość.

Używane przeze mnie tutaj określenie „polityczność” [the political] można najlepiej zrozumieć poprzez odróżnienie go od „polityki” [politics]. Choć oba należą do domeny, w której społecznemu życiu nadawana jest nadrzędna wobec niego struktura, te dwa określenia są niemalże przeciwstawne. Teoretyczka polityki Chantal Mouffe definiuje je w następujący sposób: „przez «polityczność» rozumiem wymiar antagonizmu leżący u podstaw każdego ludzkiego społeczeństwa, przez "politykę» natomiast zestaw praktyk i instytucji, które w obliczu wprowadzonego przez polityczność konfliktu tworzą porządek umożliwiający ludzkie współistnienie" ${ }^{\prime \prime 7}$. W tym rozróżnieniu polityka stano-

${ }_{55}$ Na temat „sztuki historii” zob. M.Á. Hernández Navarro, Retorcer el tiempo: Fernando Bryce y el arte de Historia, „Espacio, Tiempo y Forma” 2016, 4, s. 45-70. Szersze tło, jeszcze bez użycia nowego pojęcia, w: idem, Materializar el pasado. El artysta como historiador (benjaminiano), Murcia 2012.

${ }^{56}$ H. Bergson, Ewolucja twórcza, tłum. F. Znaniecki, Kraków 2004.

57 Ch. Mouffe, Polityczność, tłum. J. Erbel, Warszawa 2008, s. 24. To, co następuje, wywodzi się ze wstępu do mojej książki: M. Bal, Of What One Cannot Speak: Doris Salcedo's Political Art, Chicago 2010. 
wi organizację, która rozstrzyga konflikt; polityczność to domena, w której konflikt się „wydarza”. Życie społeczne jest możliwe na mocy polityczności. Może kwitnąć, być żywe albo też niebezpieczne. Nic więc dziwnego, że zwykle próbujemy uniknąć konfliktów, szukając konsensusu.

Jak dowodzi Mouffe, kultura konsensusu, będąca rezultatem polityki, nie eliminuje konfliktu; ona pozostawia go sobie samemu, tłumi i czyni podatnym na niespodziewaną, wulkaniczną erupcję. Twierdzę, że konsensus w politycznym i społecznym życiu jest tym, czym spójność jest w sztuce, zwłaszcza w scenach figuratywnych. Może być użyteczny, ale także wykluczający, i sprawiać, że niewidzialne, lecz ważne, elementy jawią się jako nieistotne szczegóły. Możemy pomyśleć o wulkanicznym charakterze rzeczywistości społecznej, patrząc na szalone spojrzenie $z$ ukosa dziko galopującego konia albo wilczą twarz mężczyzny, który niemal upada na stok zbyt stromego pagórka. Skośnie ukierunkowane spojrzenie oznacza, że nie możemy zobaczyć tego, co widzą oczy w obrazach. Widzimy jedynie, że one widzą. Ale obrazy pustych przestrzeni jasno demonstrują, co dzieje się, gdy spojrzenie z ukosa unika wspólnotowej, społecznej przestrzeni polityczności ${ }^{58}$.

Mouffe podaje przykład indywidualizmu jako ideologii; kwestia ta odnosi się jak najbardziej do Robotników w drodze do domu. Tak kontynuuje ona swoją prezentację dwóch antagonistycznych domen polityki i polityczności:

[... w myśli liberalnej dominuje podejście racjonalistyczne i indywidualistyczne, które uniemożliwia rozpoznanie natury zbiorowych tożsamości. Ten typ liberalizmu nie jest zdolny do uchwycenia pluralistycznej natury świata społecznego wraz z powodowanymi przez ten pluralizm konfliktami. Takimi, które nie mają żadnego racjonalnego rozwiązania ${ }^{59}$.

Ma to bezpośrednie przełożenie na dziwną montażową strukturę Robotników. Paradoksalnie, indywidualizm, którego punktem wyjścia jest mnogość, nie jest w stanie poradzić sobie z pluralizmem świata społecznego. Hipostaza wolności jednostki jest w rzeczy samej ogromnym ograniczeniem mnogości. Dokonując się w strefie kontaktu, spotkanie pomiędzy jednostką i dziełem sztuki, gdzie dzieło sztuki może zyskać znaczącą moc, a jednostka rzadko jest

${ }^{58}$ Odniesienie do „pustych” wczesnych prac Muncha w tym kontekście może być niezrozumiałe. Przypomnijmy, że podczas gdy główny tekst stanowi całość rozdziału pierwszego, to zostały do niego dołączone dwa ostatnie podrozdziały rozdziału drugiego, poświęconego tymże wczesnym pracom. Te i dalsze odniesienia do pustych przestrzeni w tekście Bal wiążą się z ich omówieniem we wcześniejszej części drugiego rozdziału, zatytułowanego właśnie Emptiness - przyp. tłum.

59 Mouffe, Polityczność, s. 25. 
sama, stanowi antidotum na nadmierny indywidualizm, bez konieczności wchłonięcia jednostki przez masę kosztem jej podmiotowości. Munch mówi coś takiego wizualnie, pokazując, jak wygląda owa złożona filozoficzna myśl. W skrócie - wygląda kinowo.

Refleksje te są adekwatne w stosunku do obrazów Muncha, ponieważ pomagają nam zobaczyć, w jak wspaniały, wizualny sposób artysta wyobraził sobie i zobrazował [imaged] owo napięcie pomiędzy indywidualizmem a uznaniem mnogości. To właśnie zrobił Munch, sięgając po eksperymentalny montaż: zaprezentował wspólnie trzy jednostki na pierwszym planie, ale w różnych „ujęciach”. Tych trzech mężczyzn nie zostało ściśniętych razem jako przedstawiciele tłumu, który ujmuje ich niczym owe dwa pobocza perspektywicznie oddanej drogi. Zamiast tego obraz „wyjaśnia”, że nawet w tłumie - grupie społecznej zespolonej w szczególny sposób - każdy jej członek jest odmienny. Ci mężczyźni to robotnicy, ale nie możemy ich postrzegać jako splecionych w jedno, jako klasę.

Zatem Munch dokonał niemałego wyczynu owym przedstawieniem nie politycznej sytuacji, ale politycznej myśli, którą teraz możemy zobaczyć. Wyobrażam sobie, że konstytuująca kobietę wąska figura po prawej - pośród tych wszystkich mężczyzn, na rowerze - pośród tych wszystkich pieszych to kolejny sposób wołania o indywidualizm. Choć jest ubrana jak reszta na niebiesko, wyróżnia się. Wyobrażenie sobie, co robi, zależy już od każdego $z$ widzów ${ }^{60}$.

W tym ujęciu polityczna siła sztuki opiera się na złożonym, wielorakim znaczeniu ruchu, tak jak w przypadku kinowości. Porównanie $z$ analizowanym przez Foucaulta Barem w Folies-Bergère Maneta z lat 1881-1882 może nam pomóc w dostrzeżeniu, jak daleko owo ujęcie sięga. Filozof śledzi trzy aspekty figuratywnej niekoherencji w obrazie Maneta: miejsce malarza, który musi być obecny, aby malować, ale i nieobecny, abyśmy mogli widzieć to, co widzimy; mężczyzna zwracający się do barmanki, choć musi być naprzeciwko niej, to jednocześnie nie może go tam być; perspektywa oglądu jest zarówno podniesiona, jak i obniżona. Zdaniem Foucaulta oznacza to, że Manet wynalazł tableau-objet, podkreślając materialność obrazu ${ }^{61}$.

60 Zob. wczesne komentarze na temat Robotników, zmierzające w tym kierunku: Edvard Munch: The Frieze of Life, London 1992 [1984] i E. Forssman, Menschen auf der Strasse: ein Bildthema bei Edvard Munch, w: Studieri konstvqetenskap, red. B. Linde, Stockholm 1985, s. 55-65. Zwłaszcza szczegółowa analiza Kassaya i Lütgens koncentruje się na politycznej sile indywidualizacji tych trzech mężczyzn. A.-M. Kassay, A. Lütgens, Die Arbeiterbilder Edvard Munchs, „Tendenzen” 1978, 19, s. 28.

${ }^{61}$ Analiza ta jest pośmiertnie opublikowanym wykładem wygłoszonym w Tunisie w roku 1971 (M. Foucault, La peinture de Manet, suivi de Michel Foucault, un regard, 
Owe trzy zasygnalizowane przez Foucaulta przestrzenne nieregularności w obrazie Maneta nie są identyczne z tymi w późniejszych Robotnikach Muncha. Teza Foucaulta, że w rezultacie przestrzennych niekonsekwencji obraz nie może być widziany ze stabilnego punktu oglądu, jest mniej radykalna niż oparty na montażu kinowy aspekt Robotników Muncha. Z Maneta koncentracji na materialności Munch przenosi uwagę na widza. W Robotnikach widz jest wzywany, by zamiast dokonać rozpoznania w kognitywnym, ikonograficznym sensie, że mężczyźni są częścią masy robotników, uznać - w uprawomocniającym sensie tego słowa - ich indywidualność, pomimo (produktywna dwuznaczność) ich robotniczej profesji. A by to zrobić, Munch sięga po formę - kinowy montaż.

Podobnie w Pod górę z sankami dwuznaczność wyspy widzianej frontalnie, albo łodzi widzianej z góry, służy ustaleniu, że dwie postaci mężczyzn nie są przedstawione lub „sfilmowane” $z$ tej samej perspektywy. To rozróżnienie domaga się dla każdego z nich różnicy. Mężczyzna w zielonym ubraniu wydaje się oddalać od niemalże upadającej postaci ciągnącego sanki, zamiast mu pomagać. Za chwilę pagórek będzie pusty - tak pusty jak przestrzenie we wczesnych pracach Muncha. Jeśli mamy tam do czynienia z polityczną mocą, to nie tyle spoczywa ona w motywie czy w wypowiedzi na temat robotników jako jednostek i grupy jednocześnie, ile zwłaszcza w sposobie, w jaki prace te zmuszają nas do dostrzeżenia, odczucia i uświadomienia sobie groźby tego, co ma z nich wyniknąć - co puste przestrzenie ukazują tak klarownie.

\section{RUCH W POLITYCZNOŚCI}

Oto, co wiąże się ze sztuką, która łączy przestrzeń, czas i formę za pomocą wielorakich ruchów podsumowanych przeze mnie w słowie „kinowość". Z tymi trzema wymiarami nie tylko związana jest jej ontologia, ale także zdolność funkcjonowania, zrobienia czegoś: bycia performatywną. A ponieważ sztuka, tak jak i kuratorstwo, istnieje w sferze publicznej oraz dla niej,

red. M. Saison, Paris 2004, s. 47. Jego interpretacja przestrzennej konstrukcji Baru stanowi przeciwieństwo jego interpretacji Las Meninas Velázqueza, która nie spodobała się tylu poważnym historykom sztuki, winiącym raczej „prawdę” perspektywy, zamiast podążyć za Foucaultem w jego próbie rewizji tej ortodoksji. Zob. rozwinięcie tej dyskusji w: M. Bal, Reading 'Rembrandt': Beyond the Word-Image Opposition, Cambridge-New York 1991, s. 247-285. Coś podobnego zdarzyło się w niniejszej analizie, e.g. T. de Duve, "Ah! Manet...." Comment Manet a-t-il construit Un bar aux Folies-Bergère?, w: Foucault, La peinture...., s. 95-112. 
oba te elementy nieuchronnie mają swój udział w polityczności. Ruch wpisuje dzieło sztuki w czasoprzestrzeń. Mobilizuje widzów, przygotowuje ich do działania, włączając w to zmianę ich spojrzenia, gdy są przywiązani do tendencyjnych opinii - Flauberta idées reçues. Taka perspektywa bierze pod uwagę ruch w jego naleganiu na dynamiczną naturę sfery publicznej albo na polityczność.

Jednak nie oznacza to, że politykę i polityczność można rozdzielić. One ze sobą współegzystują, ponieważ obie domeny łączy również przestrzenny aspekt, na którym koncentruje się sztuka wizualna. Amerykańska politolożka Wendy Brown opiera polityczność na poczuciu przestrzeni. Dla Brown warunkami funkcjonowania domeny publicznej są formacja sądów, performowanie demokratycznych aktów oraz dostępność „politycznych przestrzeni”62. To właśnie owe polityczne przestrzenie łączą omówione tu dzieła sztuki. Przestrzenie, które stworzył Munch, demonstrują pustkę, która wyłania się, gdy polityczne przestrzenie nie mogą się rozwinąć.

Sztuka zmusza widzów, na których wpływa, by dokonywali sądów w takich kwestiach, jak na przykład sprawiedliwość albo semiotyczne oddziaływanie, albo afektywna intensywność, a nie prawda. Dokonywanie takich sądów stanowi ćwiczenie w demokratycznej sprawczości. W moim rozumieniu "demokratyczność" [the democratic] wymaga kontekstów, w których można mówić o problemach wchodzących w skład polityczności. Tam, gdzie nie jest to możliwe („o czym nie można mówić”), należy wynaleźć inne środki, aby zapobiec Wittgensteinowskiej konkluzji z Traktatu, która ma straszliwie negatywny wydźwięk ze względu na swoją uległość („o tym trzeba milczeć"). Myślę, że Foucault nie byłby zadowolony z konkluzji swojego kolegi ${ }^{63}$.

Taka logika ucisza sprawczość. W kategoriach wizualnych czyniłaby niewidocznym to, co tworzy niewidoczność w ramach tego, co widoczne (Foucault). Przestrzenie, których wymaga demokratyczna sprawczość, to miejsca, w których nie tylko pozwala się, ale i aktywnie umożliwia i stymuluje sądy i akty demokratycznej dysputy - nawet dokonywane po cichu, w postaci myśli i rozważań. Sztuka może być polityczna, gdy otwiera takie

62 Zob. W. Brown, Postmodern Exposures, Feminist Hesitations, w: eadem, States of Injury: Power and Freedom in Late Modernity, Princeton 1995, s. 30-51 - przyp. tłum.

63 Zob. L. Wittgenstein, Tractatus Logico-Philosophicus, tłum. B. Wolniewicz, Warszawa 2001. Zastanawiam się nad tym, a także nad odmową zawartą w wyciągniętych wnioskach, jako wskazówką do zrozumienia afektywnej jakości sztuki; to, o czym nie można mówić, należy pokazać. Zrobiłyśmy na tej bazie film: M. Bal, M. Williams Gamaker, A Long History of Madness (2012), zob. www.crazymothermovie.com. Projekt ten opierał się na F. Davoine, Mother Folly: A Tale, tłum. J.W. Miller, Stanford 2014. 
przestrzenie. Sztuka na wystawie - a zatem poddana kuratorskiemu działaniu - konstruuje polityczne przestrzenie za pomocą czasu, przestrzeni i formy. Muzeum, galeria i inne dostępne publiczne przestrzenie, gdzie sztuka może ożywać, są, albo powinny być, takimi politycznymi przestrzeniami. Czasoprzestrzeń muzeum pozwala na wydarzenie się wizualnego dialogu, takiego, którego owe patrzące z ukosa postaci - co smutne albo fascynujące nie były w stanie albo nie chciały stworzyć, albo były na to zbyt nieśmiałe, co skutkowało społeczną pustką. 
